\title{
Syn-Eruptive Taphoflora From The Agua De La Zorra Formation (Upper Triassic) Cuyana Basin, Mendoza, Argentina
}

\author{
"Tomás Ezequiel Pedernera1, Eduardo Guillermo Ottone², Adriana Cecilia Mancuso", \\ Cecilia Andrea Benavente ${ }^{1}$, Fernando Abarzua ${ }^{1}$
}

\begin{abstract}
Instituto Argentino de Nivología, Glaciología y Ciencias Ambientales, CCT-CONICET, Mendoza. Adrián Ruiz Leal s/n, Parque Gral. San Martín. Casilla de Correo 330, M5502IRA Mendoza, Argentina.

tpedernera@mendoza-conicet.gov.ar; cebenavente@gmail.com; amancu@mendoza-conicet.gov.ar;fabarzua@mendoza-conicet.gov.ar

2 Instituto de Estudios Andinos Don Pablo Groeber (IDEAN), CONICET-Universidad de Buenos Aires, Departamento de Ciencias Geológicas, Facultad de Ciencias Exactas y Naturales, pabellón n², Ciudad Universitaria, C.P. C1428EHA, Buenos Aires, Argentina. ottone@gl.fcen.uba.ar
\end{abstract}

*Autor de correspondencia: tpedernera@mendoza-conicet.gov.ar

\begin{abstract}
In the North of Mendoza Province, at Paramillos de Uspallata locality, Triassic sedimentary rocks outcrop. These Triassic beds are grouped in four formations: Paramillos, Agua de la Zorra, Portezuelo Bayo and Los Colorados. The Agua de la Zorra Formation is characterized by deposition in a deltaic and lacustrine system. The aims of this contribution are: (1) to realize a systematic study of new plant remains found in the Agua de la Zorra Formation and (2) to analize the influence of the potential of preservation and the volcanism in the Agua de la Zorra taphoflora in contrast with other Triassic units. Plant remains were systematically collected and compared with taphofloras from other Triassic formations of the Cuyana Basin. The systematic study from the Agua de la Zorra Formation allowed the determination of 21 taxa, nine of which have been cited in a previous contribution and 12 were described for the first time for the Agua de la Zorra Formation. There are differences in the taxonomic diversity between the taphofloras recovered from Potrerillos and Paramillos formations and these differences are linking with differences in biostratinomic process in each fluvial system and linked with the evidence of volcanic processes in these areas. The differences in diversity in the taphofloras of the Cacheuta and Agua de la Zorra formations can be more associated to ecological differences than variations in the taphonomic processes in each of the lake systems.
\end{abstract}

Keywords. Taphoflora, Volcanism, Triassic, Systematic.

RESUMEN. Tafoflora sin-eruptiva de la Formación Agua de la Zorra (Triásico Superior) Cuenca Cuyana, Mendoza, Argentina. En la localidad de Paramillos de Uspallata, al Norte de la provincia de Mendoza, afloran rocas sedimentarias asignadas al Triásico. Estas capas triásicas están agrupados en cuatro formaciones: Paramillos, Agua de la Zorra, Portezuelo Bayo y Los Colorados. La Formación Agua de la Zorra se caracteriza por sedimentos depositados en un ambiente deltaico-lacustre. Los objetivos de este trabajo son: (1) realizar un studio sistemático de nuevos restos fósiles de plantas colectados en la Formación Agua de la Zorra y (2) analizar la influencia del volcanismo en el área de Agua de la Zorra sobre el potencial de preservación de la tafoflora en la unidad en contraste con otras unidades triásicas. Los restos de plantas fueron recolectados de manera sistemática y comparados con otras tafofloras provenientes de otras formaciones triásicas de la Cuenca Cuyana. El estudio sistemático de la tafoflora de la Formación Agua de la Zorra permitió la determinación de 21 taxones, nueve de los cuales ya habían sido citados en contribuciones previas y 12 fueron descriptos por primera vez para la unidad. Se registraron diferencias en la diversidad taxonómica entre las tafofloras recuperadas de las formaciones Potrerillos y Paramillos, esas diferencias estarían relacionadas con diferencias en los procesos bioestratinómicos característicos de cada sistema fluvial y con los procesos volcánicos acontecidos en dichas áreas. Las diferencias observadas en la diversidad de las tafofloras de las formaciones Cacheuta y Agua de la Zorra pueden ser asociadas más a diferencias ecológicas que a variaciones en los procesos tafonómicos propios de cada sistema lacustre. 


\section{Introduction}

Ecological responses following explosive volcanic eruption involve a variety of rapid and gradual changes. The disruptive negative effect on the environment subsequent to eruptive events, as changes in the physicschemistry conditions and sedimentary processes and in vegetal biodiversity, have been reported (Dale et al., 2005; Lindermeyer et al., 2010). Ecological disturbance is "any relatively discrete event in time that disrupts ecosystem, community, or population structure and changes resources, substrate availability, or the physical environment" (White and Pickett, 1985). The volcanic events have negative effects over ecological process, especially on plant communities, and affect to the sedimentary processes and taphonomic processes (Behrensmeyer and Hook, 1992). Several studies evaluated the ecological disturbance and vegetation recovery in some recent models (Wood and Del Moral, 1988; Del Moral and Wood, 1988, 1993; Del Moral and Grishin, 1999; Swanson et al., 2013). However, the studies regarding the fossil record are less abundant (Brea et al., 2009; Poma et al., 2009; Ottone et al., 2011; Rößler et al., 2012).

In the North of Mendoza Province, at Paramillos de Uspallata locality near Uspallata town, outcropping sedimentary rocks are referred by Harrington (1971) to the Cacheuta Group and include four formations (from base to top) Paramillos, Agua de la Zorra, Portezuelo Bayo and Los Colorados; assigned to the Triassic Period. Three of these units were influenced by the active volcanism that affected the southwest of Gondwana margin during the Permo-Triassic.

Correlation of the Paramillos de Uspallata units with the Uspallata Group outcropping at the well-known Triassic localities of Cacheuta and Potrerillos on the Mendoza River (Strelkov and Alvarez, 1984; Kokogian et al., 1993; Cortés et al., 1997; Stipanicic and Zavattieri, 2002) has been difficult. In this scenario, different criteria of correlation were postulated (Stipanicic et al., 2002). Several authors, as Groeber and Stipanicic (1952), considered the Agua de la Zorra Formation (Paramillos de Uspallata) analogous with the Potrerillos and Cacheuta formations (at Mendoza River), whilst others, as Ramos and Kay (1991), and Kokogian et al. (1993) correlated the Agua de la Zorra Formation with the Las Cabras Formation (at Mendoza River).

The paleontological record of the Triassic beds of Paramillos de Uspallata is diverse and includes spinicaudatan and fishes (Geinitz, 1876; Albanesi et al., 2009), trace fossils (Melchor et al., 2001), reptiles (Rusconi, 1967), possible temnospondyl amphibians (Stipanicic and
Marsicano, 2002) and a permineralized forest (Brea et al., 2008). Different authors described plants remains in the Paramillos and Portezuelo Bayo formations (Brea and Artabe, 1994, 1999; Brea, 1996a, 1996b, 1997, 2000; Brea et al., 2009). However, only one contribution (Ottone et al., 2011) dealt with the systematic study of the Agua de la Zorra Formation paleoflora.

The aims of this contribution are: (1) to present a detailed taxonomic study of new plant fossils recovered from the Agua de la Zorra Formation; and (2) to analize the influence of the potential of preservation and the volcanism in the Agua de la Zorra paleoflora record, contrasting these parameters with those observed in other equivalent Triassic taphofloras.

\section{Geological setting}

Paramillos de Uspallata is a sub-basin of the Cuyana Basin, one of the nonmarine rift basins developed during the break-up of Pangea supercontinent (SW Gondwana) during the Triassic (Uliana and Biddle, 1988). This extensional continental basin includes fluvial and lacustrine systems (Ramos and Kay, 1991).

The sub-basin earliest infill corresponds to the Paramillos Formation. This is a volcaniclastic unit characterized by conglomerates, lithic and tuffaceous sandstones with interbedded shales and tuffs. The depositional environment of these sediments was interpreted as a highly sinuous or meandering fluvial system associated with floodplain deposits (Brea, 1995). Brea et al. (2009) assigned the Paramillos Formation to the late Middle Triassic based in the plant paleocommunities recorded in this area. Cingolani et al. (2017) analyzed zircons by the U-Pb methodology (LA-ICP-MS) and obtained approximate ages of $239.6 \pm 1.3$ $\mathrm{Ma}$ (Ladinian). Overlaying the Paramillos Formation there is the Agua de la Zorra Formation. This unit is dominated by bituminous shales and marls with subordinated interbedded fine-grained sandstones and mudstones with peperitic, olivine basalts interbeded (Harrington, 1971; Brea et al., 1999; Ottone et al., 2011). The paleoenviroment is interpreted as a fluvial-lacustrine system with episodic incursions of lava flow in the aquatic medium (Cortés et al., 1997; Ottone et al., 2011). K/Ar ages of $235 \pm 5 \mathrm{Ma}$ and $240 \pm 10 \mathrm{Ma}$ were obtained in the basalts by Massabie (1986) and are also recorded in Linares (2007). The sedimentary record of the overlaying Portezuelo Bayo Formation is dominated by tuffaceous sandstones of fine to medium grain size with interbedded tuffs, some conglomerates and shales (Harrington, 1971; Stipanicic and Morel, 2002a). The sedimentary environment is interpreted as sinuous fluvial 
system dominated by flood plain deposits. Los Colorados Formation covers the Portezuelo Bayo Formation and is characterized by sandstones with interbedded conglomerates and is referred to as Upper Triassic (Harrington, 1971; Stipanicic and Morel, 2002b).

\subsection{Agua de la Zorra paleoenvironment}

The Agua de la Zorra Formation was deposited in a deltaic and lacustrine system (Table 1, Fig.1.1 and 1.2). Facies association AZ-a included dark greenish gray fine-grained, well-sorted massive sandstones (Sm), with vesicles of $0.5 \mathrm{~cm}$ in diameter and carbonate cemented nodules; light brownish gray massive muddy siltstones (Fm); moderate light gray coarse-grained, well sorted sandstones with ripple cross-stratification ( $\mathrm{Sr}$ ), and through crossstratification pebbly sandstones (St) interpreted as lower delta plain associated with mouth bars at the delta front. The Facies association AZ-b is dominated by black, olive black, greenish red, and greenish black finely laminated mudstones (F1); light brownish gray massive muddy siltstones (Fm), horizontally laminated fine to coarsegrained well sorted-sandstone (Sh), and massive white tuff (Tf) interpreted as prodelta to offshore lacustrine deposits.

\section{Materials and methods}

Plant remains were systematically collected in the Agua de la Zorra Formation at the Paramillos de Uspallata locality in several fieldtrips between 2015 and 2017. Eighteen fossil-bearing horizons were reported and several specimens were collected from them. The fossil-bearing horizons are identified with roman numbers from I to XVIII (Fig. 1. 2).

The recovered material includes leaf fragments, stems associated with leaves and reproductive structures. They are preserved as carbonaceous compressions and/or impressions in black shales and yellow mudstones from different levels of the unit. They occurred as fragmented plant elements, with variable size, densely packed or isolated, and with weak orientation preferences.

The specimens were studied with a binocular stereoscopic microscope WILD Heerbrugg M8 and they were photographed with a Canon Power Shot SD1200 IS (10 megapixels) digital camera. Reproductive structures were studied with a binocular stereoscopic microscope LEICA M60 with integrated camera Leica DMC2900.

The fossil material is housed at the Paleobotanical Collection of the Instituto Argentino de Nivología, Glaciología y Ciencias Ambientales (IANIGLA) in Mendoza city, Argentina, under the prefix IANIGLA-PB, and at the Paleobotanical Collection of the Departamento de Ciencias Geológicas, Facultad de Ciencias Exactas y Naturales, Universidad de Buenos Aires under the prefix BAFC-Pb.

For the systematic classification we followed the proposal by Stewart and Rothwell (1993) used by Zamuner et al. (2001), Artabe et al. (2007) and Morel et al. (2010, 2011). In the case of ferns, we adhere with Smith et al. (2006) proposal, and for the identification of fructifications we follow Anderson and Anderson (2003).

\section{Systematic paleobotany}

\author{
Subdivision Euphyllophytina Kenrick and \\ Crane, 1997 \\ Class Polypodiopsida Cronquist et al., 1966 \\ Order Equisetales de Candolle, 1804 ex von \\ Berchtold and Presl, 1820 \\ Family Undetermined \\ Genus Neocalamites Halle, 1908
}

Type species. Neocalamites hoerensis (Schimper, 1869) Halle, 1908

Neocalamites sp.

Figure 2. 1,2

Description. Fragmentary compressions and impressions of articulate ribbed axis, 0.9 to $11.8 \mathrm{~cm}$ long, up to $4 \mathrm{~cm}$ wide at the nodes; ribs are $0,1 \mathrm{~cm}$ wide and up to $0.1 \mathrm{~cm}$ separated on large axes; nodes displaying circular structures, $0,1 \mathrm{~cm}$ in diameter, interpreted as probable branches.

Comments. Unbranched articulate ribbed axes associated with leaves not forming a foliar sheat are currently referred to Neocalamites. The presence of associated sporangiophores allows different phylogenetic relationships to this taxon. Boureau (1964) included Neocalamites in the Family Apocalamitaceae (Radczenko, 1957), whilst Good (1975), Meyen (1987), and Escapa and Cúneo (2004) in the Family Equisetaceae (De Candolle, 1804). Recently, Elgorriaga et al. (2018) consider the Neocalamites species as a natural and independent sister group of the Equisetaceae, and not directly related to the Calamitaceae clade, as suggested by Stewart and Rothwell (1993). Following Elgorriaga et al. (2018), and considering that the Agua de la Zorra Formation plant fossils lack associated sporangiate organs, the suprageneric assignation of our material remains undeterminate. In the studied material, the presence of nodes with no evidence of basally fused leaves forming a sheath allows the inclusion of our material in Neocalamites, however, pending discovery of better preserved specimens, the Agua de la Zorra material is left in open nomenclature. 
TABLE 1. FACIES ASSOCIATIONS AND THEIR CHARACTERISTICS DEFINED FOR THE AGUA DE LA ZORRA FORMATION (TRIASSIC) AT USPALLATA.

\begin{tabular}{|c|c|c|c|c|c|c|c|}
\hline $\begin{array}{l}\text { Facies } \\
\text { Association } \\
\text { (FA) }\end{array}$ & Facies & Sedimentary structures & Bed geometry & Vertical and lateral relations & Fossil content & Processes & $\begin{array}{c}\text { FA } \\
\text { Interpretation }\end{array}$ \\
\hline \multirow[t]{4}{*}{ A } & $\begin{array}{l}\text { Cemented massive } \\
\text { sandstones }(\mathrm{Sm})\end{array}$ & $\begin{array}{l}\text { Fine-grained, well-sorted massive sandstones } \\
\text { of dark greenish gray color }(5 \mathrm{GY} 4 / 1) \text {, with } \\
\text { vesicles of } 0.5 \mathrm{~cm} \text { in diameter, carbonate } \\
\text { cement interdigitations and carbonate } \\
\text { cemented nodules }\end{array}$ & Tabular, 1-14 m thick & Underlies and overlies facies Fl & - & $\begin{array}{l}\text { Diagenetically } \\
\text { altered } \\
\text { sandstones }\end{array}$ & \multirow{4}{*}{$\begin{array}{l}\text { Lower } \\
\text { delta plain } \\
\text { associated } \\
\text { with mouth } \\
\text { bars at the } \\
\text { delta front }\end{array}$} \\
\hline & $\begin{array}{l}\text { Massive siltstones } \\
(\mathrm{Fm})\end{array}$ & $\begin{array}{l}\text { Massive muddy siltstones, color is light } \\
\text { brownish gray }(5 \text { YR6/1) }\end{array}$ & $\begin{array}{l}\text { Tabular, } 0.3-0.6 \mathrm{~m} \\
\text { thick }\end{array}$ & $\begin{array}{l}\text { Overlies facies } \mathrm{Sm}, \mathrm{Sr}, \mathrm{F} 1 \text { and } \\
\text { underlies facies } \mathrm{Sr}, \mathrm{St}, \mathrm{Fl}\end{array}$ & Trace fossils & $\begin{array}{l}\text { Suspension settle- } \\
\text { out }\end{array}$ & \\
\hline & $\begin{array}{l}\text { Ripple cross } \\
\text { sandstones (Sr) }\end{array}$ & $\begin{array}{l}\text { Coarse-grained, well sorted sandstones, } 1 \mathrm{~cm} \\
\text { thick sets and } 2 \mathrm{~cm} \text { thick cosets, siliciclasts } \\
\text { are subrounded to subangular, containing } \\
\text { angular quartz, K-feldspar and muscovite, } \\
\text { color is moderate light gray (N6) }\end{array}$ & Tabular, $0.3 \mathrm{~m}$ thick & Underlies and overlies facies Fm & - & Tractive flows & \\
\hline & $\begin{array}{l}\text { Trough cross } \\
\text { sandstones }(\mathrm{St})\end{array}$ & $\begin{array}{l}\text { Pebbly sandstones with through cross } \\
\text { stratification, sets are } 5 \mathrm{~cm} \text { thick in cosets } \\
\text { of } 20 \mathrm{~cm} \text { thick, coarsening upwards }\end{array}$ & Tabular, $2 \mathrm{~m}$ thick & $\begin{array}{l}\text { Underlies facies F1 and overlies } \\
\text { facies St }\end{array}$ & - & $\begin{array}{l}\text { Channelized } \\
\text { tractive flows }\end{array}$ & \\
\hline \multirow[t]{3}{*}{ B } & $\begin{array}{l}\text { Finely laminated } \\
\text { mudstones (Fl) }\end{array}$ & $\begin{array}{l}\text { Finely laminated mudstones, laminae are } 1 \\
\text { mm thick, color range from black (N1) to } \\
\text { olive black ( } 5 \text { Y } 2 / 1) \text { to greenish red ( } 5 \mathrm{R} 4 / 2) \\
\text { to greenish black ( } 5 \mathrm{YR} 2 / 1)\end{array}$ & $\begin{array}{l}\text { Tabular, } 0.5-11 \mathrm{~m} \\
\text { thick }\end{array}$ & Overlies facies $\mathrm{Sm}, \mathrm{Sh}, \mathrm{St}, \mathrm{Fm}, \mathrm{Tf}$ & $\begin{array}{l}\text { Plant remains, } \\
\text { fish scales and } \\
\text { conchostracans }\end{array}$ & & \multirow{4}{*}{$\begin{array}{l}\text { Prodelta } \\
\text { to offshore } \\
\text { lacustrine }\end{array}$} \\
\hline & $\begin{array}{l}\text { Massive siltstones } \\
(\mathrm{Fm})\end{array}$ & $\begin{array}{l}\text { Massive muddy siltstones, color is light } \\
\text { brownish gray }(5 \text { YR6/1) }\end{array}$ & $\begin{array}{l}\text { Tabular, } 0.3-0.6 \mathrm{~m} \\
\text { thick }\end{array}$ & $\begin{array}{l}\text { Overlies facies } \mathrm{Sm}, \mathrm{Sr}, \mathrm{Fl} \text { and } \\
\text { underlies facies } \mathrm{Sr}, \mathrm{St}, \mathrm{Fl}\end{array}$ & Trace fossils & $\begin{array}{l}\text { Suspension settle- } \\
\text { out }\end{array}$ & \\
\hline & $\begin{array}{l}\text { Horizontally } \\
\text { laminated } \\
\text { sandstone (Sh) }\end{array}$ & $\begin{array}{l}\text { Fine to coarse-grained well sorted-sandstone, } \\
\text { lamination is } 0.5 \mathrm{~cm} \text { thick }\end{array}$ & $\begin{array}{l}\text { Tabular to lenticular, } \\
0.3-0.6 \mathrm{~m} \text { thick }\end{array}$ & Underlies and overlies facies Fl & - & $\begin{array}{l}\text { Channelized to } \\
\text { non-channelized } \\
\text { tractive flows }\end{array}$ & \\
\hline & Tuff (Tf) & Massive, white color (N9) & Tabular, $0.5 \mathrm{~m}$ thick & Underlies and overlies facies Fm. & - & Ash fall & \\
\hline
\end{tabular}



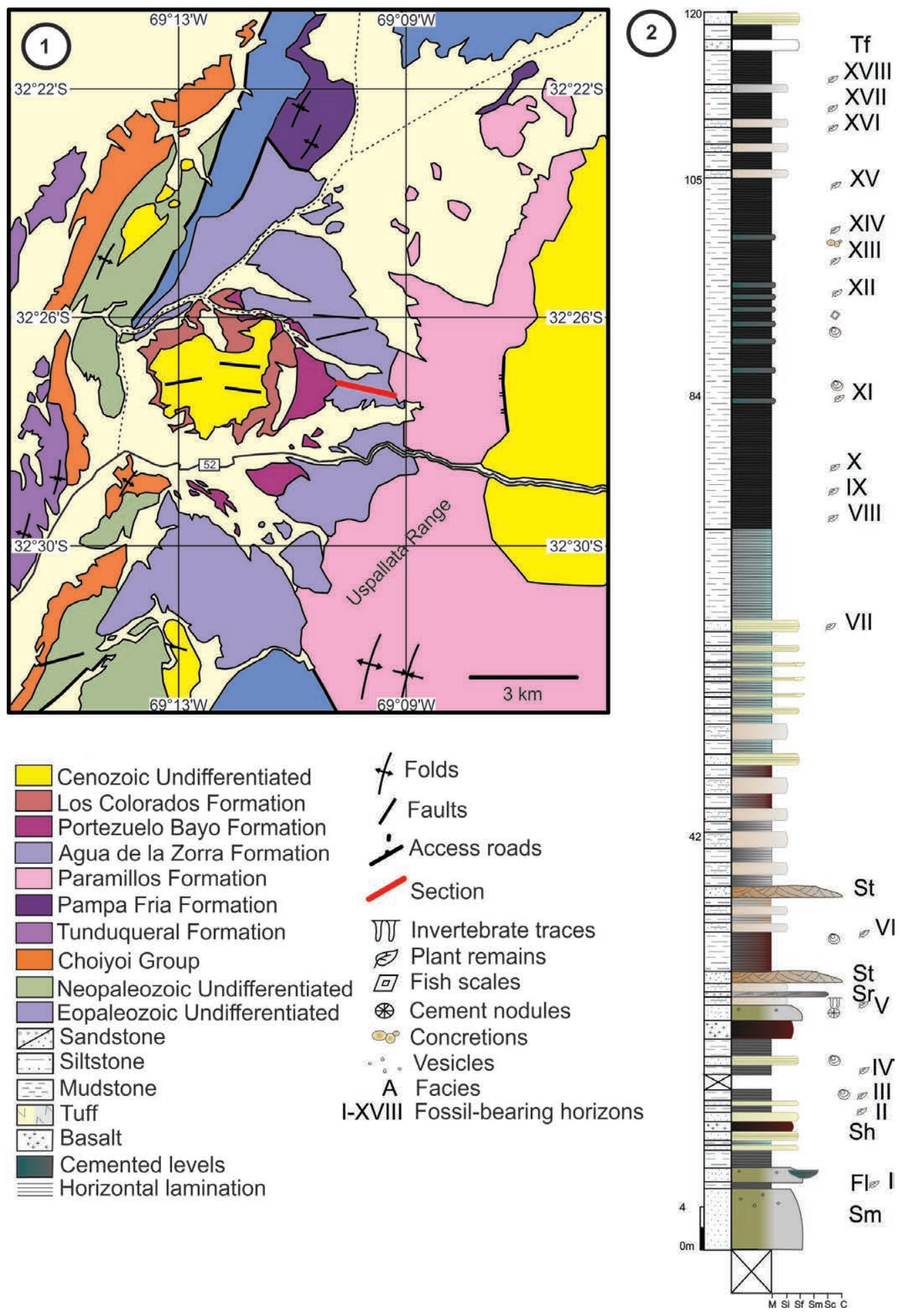

FIG. 1. 1. Geologic map of the Paramillos de Uspallata, Mendoza, Argentina. 2. Detailed stratigraphic section of Agua de la Zorra Formation at the Paramillos de Uspallata and stratigraphic provenience of materials. St, Sr, Sh, Fl, Sm, Tf are lithofacies mentioned in Table 1. 


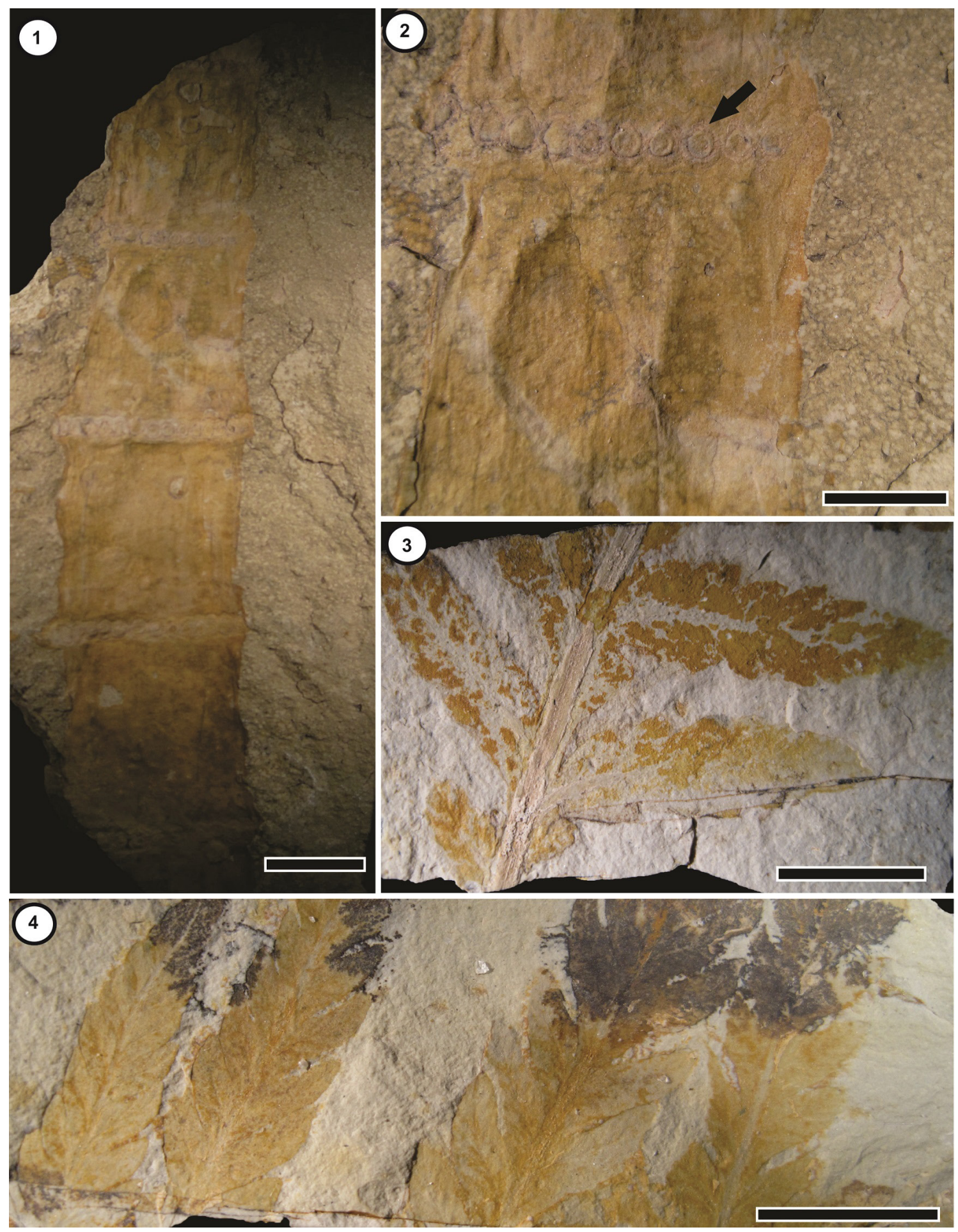

FIG. 2. 1. Neocalamites sp Halle, 1908, IANIGLA-PB-679. Scale bar=1 cm. 2. Detail of nodes the arrow mark incertion branch's structrure. Scale bar= $=.5 \mathrm{~cm}$. 3. Cladophlebis sp. Cf. C. mesozoica Frenguelli, 1947. IANIGLA-PB-682 Scale bar=1 cm. 4. Cladophlebis kurtzii Frenguelli, 1947. IANIGLA-PB-681 Scale bar=1 cm. 


\author{
Order Osmundales Link, 1833 \\ Family Osmundaceae Martynov, 1820 \\ Genus Cladophlebis Brongniart, 1849 emend. \\ Frenguelli, 1947 \\ Type species. Cladophlebis albertsii (Dunker, 1846) \\ Brongniart, 1849 \\ Cladophlebis kurtzi Frenguelli, 1947 \\ Figure 2. 4
}

Synonymy in Herbst (1971)

Description. Fragmentary impressions of bipinnate fronds bearing subopposite subcircular and elongate pinnules, attached with an angle ca. $45^{\circ}$. Pinnules decurrent at the base, entire margins and apex slightly rounded. With a single mid-vein and badly preserved secondary venation, but in some specimens, it is possible to see secondary veins forking near the insertion area with the mid vein.

Comments. The genus Cladophlebis was created by Brongiart (1849) to refer to sterile filiciform fronds of the Paleozoic and Mesozoic that can not be assigned with certainty to a natural family, however, it is known that some species correspond to the family Osmundaeae (Boureau and Doubinger, 1975). Nevertheless, Cladophlebis leaves are also present in Cyatheaceae and Dennstaediaceae (Villar de Seoane, 1996), and in ferns of uncertain affinity (Carrizo et al., 2011). Cladophlebis leaves of the Agua de la Zorra Formation are referred to the Osmundaceae because Cyatheaceae and Dennstaediaceae records begin in the Jurassic (Smith et al., 2006).

The species Cladophlebis kurtzi Frenguelli, 1947 includes laminate, alternate, well spaced, lanceolate pinnules with entire margins, and secondary veins bifurcating once near the base. As noted by Frenguelli (1947), the presence of smaller, triangular-ovate pinnules of acute apex and confluent bases, as seen in the Agua de la Zorra material, indicates a distal position in the pinnate leaves.

\section{Cladophlebis sp. cf. C. mesozoica Kurtz in Bodenbender, 1911 ex Frenguelli, 1947}

Figure 2. 3

\section{Synonymy in Herbst (1971)}

Description. The specimen is an impression of fragment of a bipinnate frond bearing subopposite, broadly attached pinnules, $1.5-2 \mathrm{~cm}$ long, $0.5 \mathrm{~cm}$ wide; pinnules constricted anadromically and decurrent catadromically with entire to slightly lobed margin, a rounded apex, and badly preserved secondary venation.
Comments. This species includes alternate shallowly lobed pinnules, bearing two forked secondary veins. The morphology of pinnules is variable in relation of their position in the pinnae, difficulting the assignment of fragmentary material (Herbst, 1971).

\section{Class Gymnospermopsida sensu Stewart and Rothwell, 1993 Order Umkomasiales Meyen, 1984 Family Umkomasiaceae Petriella, 1982}

Remarks. Umkomasiaceae was traditionally known as Corystospermaceae (Thomas, 1933), a descriptive name, not based on a validly published fossil-generic name. Descriptive family names are proscribed by the Code (Art. 18.1 of the ICN) (Doweld, 2017; Turland et al., 2018).

Umkomasiaceous leaves are morphologically variable, but shear similar cuticles, so, several authors (Townrow, 1957; Bonetti 1966; Archangelsky, 1968; Anderson and Anderson, 1970, 1983; Holmes and Ash, 1979) refer all of them to the genus Dicroidium. However, considering that the preservation of mummified remains is relatively scarce, another group of authors (Frenguelli, 1943, 1944; Retallack 1977; Petriella, 1979; Artabe, 1985, 1990; Morel, 1994; Gnaedinger and Herbst, 1998a) discriminated different genera of distinctive morphology as Dicroidium, Johnstonia, Xylopteris and Zuberia. This contribution stands this last position.

\section{Genus Dicroidium Gothan, 1912 \\ Type species. Dicroidium odontopteroides \\ (Morris, 1845) Gothan, 1912 \\ Dicrodium argenteum (Retallack) Gnaedinger in \\ Gnaedinder and Herbst, 2001 \\ Figure 3. 1}

\section{Synonymy in Retallack (1977) and in Gnaedinger and Herbst (2001)}

Description. Frond fragments up to $6 \mathrm{~cm}$ long with subopposite, subcircular pinnules displaying slightly constricted bases, entire margins and a rounded apex.

Comments. The Agua de la Zorra Formation specimens fit well with the forms figured by Retallack (1977) and Gnaedinger and Herbst (2001).

Dicrodium crassum (Menéndez) Petriella, 1979

Figure 3.6

Synonymy in Retallack (1977) and Gnaedinger and Herbst (1998a, 2001). 
Description. Fragments of dichotomously divided fronds up to $5.5 \mathrm{~cm}$ long with subopposite, subcircular pinnules at ca. $45^{\circ}$ to rachis.

Comments. The species include monopinnate fronds with equidimensional to rhomboid pinnules, constricted to sometimes subpetiolae at base, acute at apex, with obtuse apical inclination, and lacking midrib (Menéndez, 1951; Petriella, 1979; Gnaedinger and Herbst 1998a; Lutz et al., 2011).

\section{Dicrodium odontopteroides (Morris) Gothan, 1912}

Figure 3. 2

Synonymy in Retallack (1977) and in Gnaedinger and Herbst (2001)

Description. Fragments of dichotomously divided frond up to $2.5 \mathrm{~cm}$ long with subcircular, subopposite pinnules enlarged at base, entire margins, rounded at apex, and odontopteroid venation.

Comments. Following Gnaedinger and Herbst (1998a, 2001), we consider that all species varieties, as previously defined by Retallack (1977), Petriella (1979), and Anderson and Anderson (1983), represent the morphological variability of a single taxon.

\section{Genus Johnstonia Walkom, 1925}

Type species. Johnstonia coriacea (Johnston, 1886) Walkom, 1925

Johnstonia coriacea (Johnston) Walkom, 1925

Figure 3. 3

Synonymy in Retallack (1977)

Description. Compressions and impressions of fronds with a dichotomously forked rachis, margin entire, leaf blade relatively broad, rounded at apex, midrib always discernible. $2.5-6 \mathrm{~cm}$ in length and $0.5 \mathrm{~cm}$ in width. Venation not preserved.

\section{Johnstonia dutoitii (Townrow) Retallack, 1977}

Figure 3. 4

Synonymy in Retallack (1977) and Gnaedinger and Herbst (2001)

Description. Fragments of pinnatifid fronds up to $6 \mathrm{~cm}$ long with a dichotomously forked rachis, margin of the leaf blade slightly lobed. Venation is not preserved.

Comments. The species includes symmetrical pinattifid fronds of lobate to rounded margins and secondary veins coalescent to the margin (Retallack, 1977).

\section{Johnstonia sp. cf. J. serrata Retallack 1977}

Figure 3. 7

Synonymy in Retallack (1977)

Description. Compressions of fragments of pinnatifid asymmetric low lobes fronds. $1.5-4.5 \mathrm{~cm}$ in length and $0.4-1 \mathrm{~cm}$ in width. Venation taeniopteroid.

Comments. Johnstonia serrata includes pinnatifid fronds with asymmetric lobes, shallow incisions in the apex margin, and taeniopteroid venation (Retallack, 1977). The doubtfull assignation is due to the bad preservation of the material.

Genus Xylopteris Frenguelli, 1943 emend. Stipanicic and Bonetti in Stipanicic et al., 1996

Type species. Xylopteris elongata (Carruthers)

Frenguelli, 1943

Xylopteris argentina (Kurtz) Frenguelli 1943 emend. Stipanicic and Bonetti in Stipanicic et al. 1996

Figure 3.5

Synonymy in Retallack (1977), Gnaedinger and Herbst (1998a) and Ottone et al., (2011)

Description. Impressions and compressions of 3-7 cm in length with linear pinnules having a coenopteroid venation. Comments. The genus Xylopteris includes bifurcate, pinnate or pinnatifid fronds, mono-, bi- or tripinnate, having linear pinnules (Frenguelli, 1943; Stipanicic et al., 1996; Ottone, 2006; Barboni et al., 2016). For specific discrimination within the genus we follow the criteria of Ottone (2006) and Ottone et al. (2011).

The species Xylopteris argentina includes monopinnate, linear, bi- or trifurcate fronds with linear pinnules and simple, usually coenopteroid, venation (Kurtz, 1921; Stipanicic et al., 1996; Ottone et al., 2011). Specimens described herein agree with the diagnosis proposed by Frenguelli (1943) and the emendation of Stipanicic and Bonetti in Stipanicic et al. (1996).

\section{Xylopteris elongata (Carruthers) Frenguelli, 1943}

Figure 3. 11

Synonymy in Ottone et al. (2011)

Description. Impressions of fronds up to $4 \mathrm{~cm}$ long with alternate to subopposite pinnae bearing linear pinnules of coenopteroid venation.

Comments. This species comprises irregularly bipinnate fronds with a dichotomously forked rachis bearing linear, simple or bifurcate foliar segments interpreted as pinnae (Carruthers, 1872; Ottone et al., 2011). 

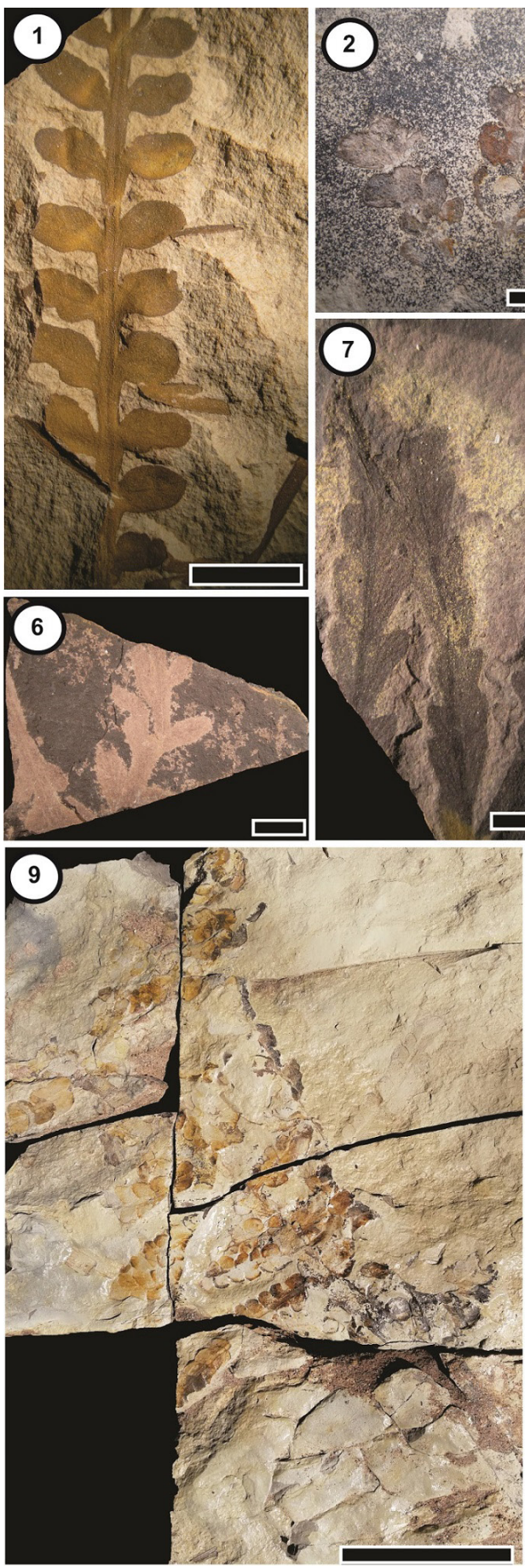
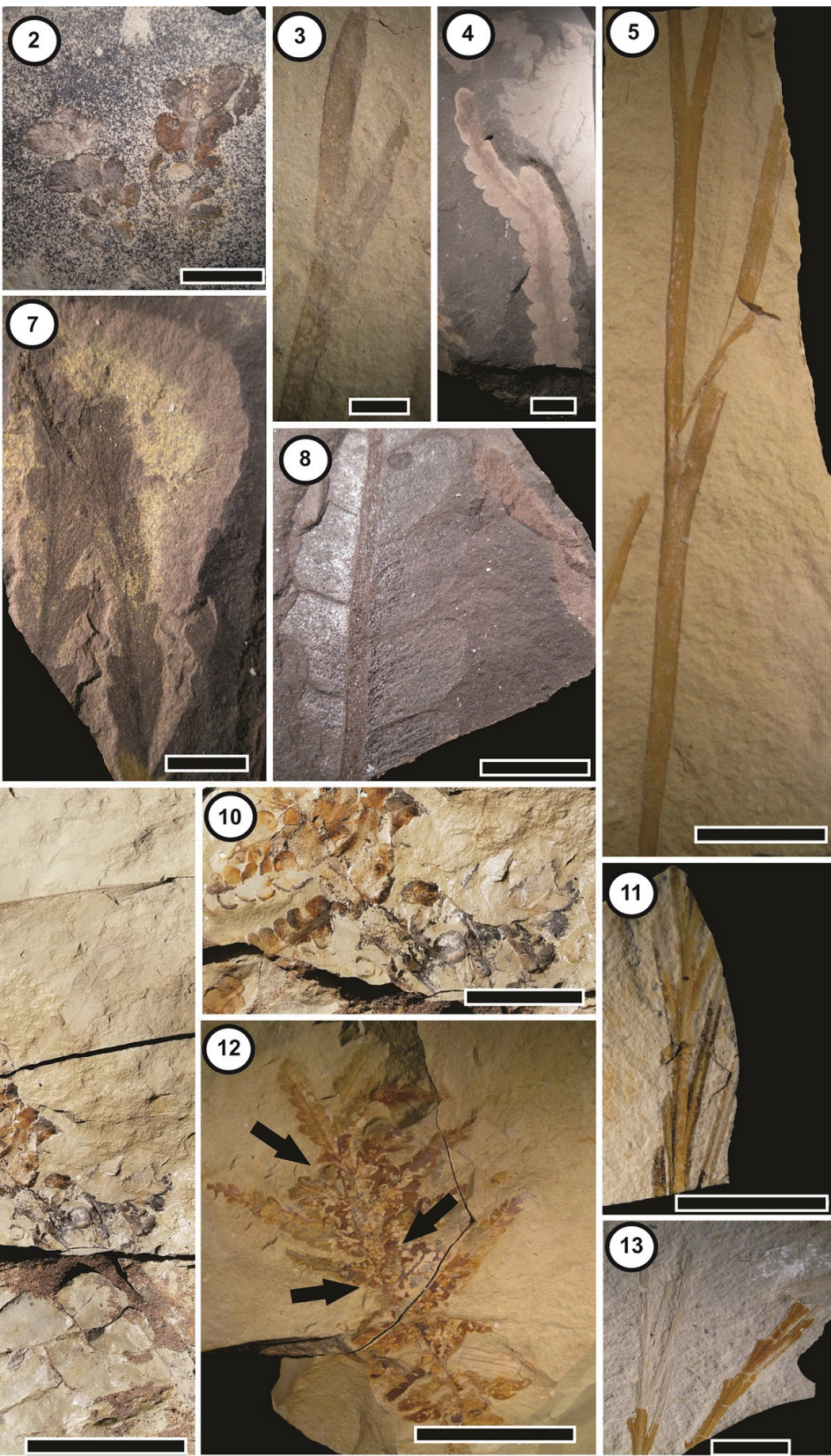

FIG. 3. 1. Dicroidium argenteum. Gnaedinder in Gnaedinder and Herbst, 2001. IANIGLA-PB-683. Scale bar=1 cm. 2. Dicrodium odontopteroides Gothan, 1912. IANIGLA-PB-686. Scale bar=1 cm. 3. Johnstonia coriacea Walkom, 1925. IANIGLA-PB-692. Scale bar $=1 \mathrm{~cm}$. 4. Johnstonia dutoitii Retallack, 1977. IANIGLA-PB-693. Scale bar $=1 \mathrm{~cm}$. 5. Xylopteris argentina Frenguelli emend. Stipanicic and Bonetti en Stipanicic et al. 1996. IANIGLA-PB-699. Scale bar=1 cm. 6. Dicrodium crassum Petriella, 1979. IANIGLA-PB-697. 7. Johnstonia sp. c.f. J. serrata Retallack 1977. IANIGLA-PB-697. Scale bar=0.5cm. 8. Zuberia feistmanteli Frenguelli, 1943. IANIGLA-PB-705. Scale bar=1cm. 9. Zuberia zuberi. Frenguelli, 1943. IANIGLA-PB-736. Scale bar $=5 \mathrm{~cm} .10$. Zuberia zuberi. Frenguelli, 1943. IANIGLA-PB-736. Scale bar $=1 \mathrm{~cm}$. 11. Xylopteris elongata Frenguelli, 1943. IANIGLA-PB-697. Scale bar=1cm. 12. Zuberia zuberi. Frenguelli, 1943. BAFC-Pb 27201. Arrow mark intercalar pinnules. Scale bar=2cm. 13. Xylopteris elongata Frenguelli, 1943. IANIGLA-PB-702. Scale bar=1cm. 
Genus Zuberia Frenguelli 1943 emend. Artabe, 1990 Type species. Zuberia zuberi (Szajnocha, 1889) Frenguelli, 1943

Zuberia feistmantelii (Johnston) Frenguelli, 1943

Figure 3. 8

\section{Synonymy in Artabe (1990)}

Description. Fragments up to $5.5 \mathrm{~cm}$ long of bipinnate fronds, bearing opposite to subopposite sub-quadrangularpinnules. The pinnules are isodiametric, width greater than $0.6 \mathrm{~cm}$. The venation is of the odontopteroid type. Sub-quadragnular interpinnules.

Comments. The genus Zuberia comprises bifurcate, imparipinnate, bipinnate, bipinnatifid or tripinnatifid fronds with rectangular, rhomboid or orbicular pinnules of odontopteroid venation, having, as a diagnostic character, intercalar pinnules (Frenguelli, 1943, 1944; Artabe, 1990). The species Zuberia feistmanteli includes bifurcate bipinnate fronds with relatively large, ca. $1 \mathrm{~cm}$ long, opposite to subopposite, subquadrangular pinnules of odontopteroid venation and greater than $0.6 \mathrm{~cm}$ (Artabe, 1990).

\section{Zuberia zuberi (Szajnocha) Frenguelli, 1943}

Figure 3. 9, 10, 12

Synonymy in Artabe (1990)

Description. Fragments up to $4.5 \mathrm{~cm}$ long of bipinnate fronds bearin opposite to subopposite quadrangular to sub-quadrangular pinnules and rounded interpinnules, showing a badly preserved venation. The size of pinnules and interpinnules are smaller than $0.5 \mathrm{~cm}$.

Comments. This species is characterized by the bifurcate bipinnate fronds with relatively small, up to $0.5 \mathrm{~cm}$ in length, opposite to subopposite, subquadrangular pinnules of odontopteroid venation (Artabe, 1990).

Order Cycadales Dumortier, 1829

Genus Taeniopteris Brongniart, 1828 emend. Cleal and Rees, 2003

Type species. Taeniopteris vittata Brogniart, 1828

\section{Taeniopteris sp. \\ Figure 4.5}

Description. Impressions and compressions of leaf fragments, $1.7-4 \mathrm{~cm}$ in length, $0.5-1.1 \mathrm{~cm}$ width, with a simple entiremargined lamina bearing a rigid midvein, $0.1-0.3 \mathrm{~cm}$ wide; lateral veins approximately perpendicular to midvein, dichotomizing near 1/2 lamina and reaching margin.

Comments. van Konijnenburg-van Cittert et al. (2017, p. 101-102) interpretation of the genus is followed here in. This artificial taxon could also be positioned in the Jurassic-Cretaceous Pentoxylales (Césari et al. 1998; Sharma, 2001). We refer the Agua de la Zorra material to the Cycadales because the Pentoxylales are uncknown in the Triassic of South America (Sharma, 2001). The specimens described herein were assigned to the genus Taeniopteris by their venation features (Anderson and Anderson, 1989). The specific attribution of the studied material is hindred by the poor preservation the specimens.

\section{Order Ginkgoales Gorozankin, 1904}

Remarks. The great morphological variability of fossil leaves, also present in extant Ginkgo biloba Linnaeus 1771, make difficult the assignation of fossil material. In this sense the taxonomical criterium of, Gnaedinger and Herbst (1999, p. 281-282) is followed here in.

\section{Genus Sphenobaiera Florin, 1936 emend. Harris and Millington in Harris et al., 1974 Type species. Sphenobaiera spectabilis \\ (Nathorst, 1906) \\ Florin, 1936 \\ Sphenobaiera sp.}

Figure 4. 6

Description. Impressions of fragments of wedge-shaped, lobed leaf, up to $2.8 \mathrm{~cm}$ in length; lamina forking, at least, one time, dichotomy occurring within $1.4 \mathrm{~cm}$ from base at an angle of $45^{\circ}$ to give two segments, $10 \mathrm{~cm}$ in width; venation parallel reaching distal margin; petiole quite undiscernabtale.

Comments. The genus includes fan-shaped leaves without petiole; close comparison of this form with previously described species is hindred by the fact that only one, fragmentary specimen was encountered.

\author{
Order Voltziales Andreanszky, 1954 \\ Family Voltziaceae Arnold, 1947 \\ Genus Heidiphyllum Retallack, 1981 \\ Type species. Heidiphyllum elongatum (Morris) \\ Retallack, 1981 \\ Heidiphyllum elongatum (Morris) Retallack, 1981 \\ Figure 4. 3,4
}

Synonymy in Retallack (1981), Anderson and Anderson (1989) and Troncoso et al., (2000)

Description. Compressions and impressions of oblate/ lanceolate to linear leaves fragments, $4 \mathrm{~cm}$ in length, and 0.3-0.5 in width, bearing 4 to 8 veins simple, parallels. The bases of leaves are not preserved. 

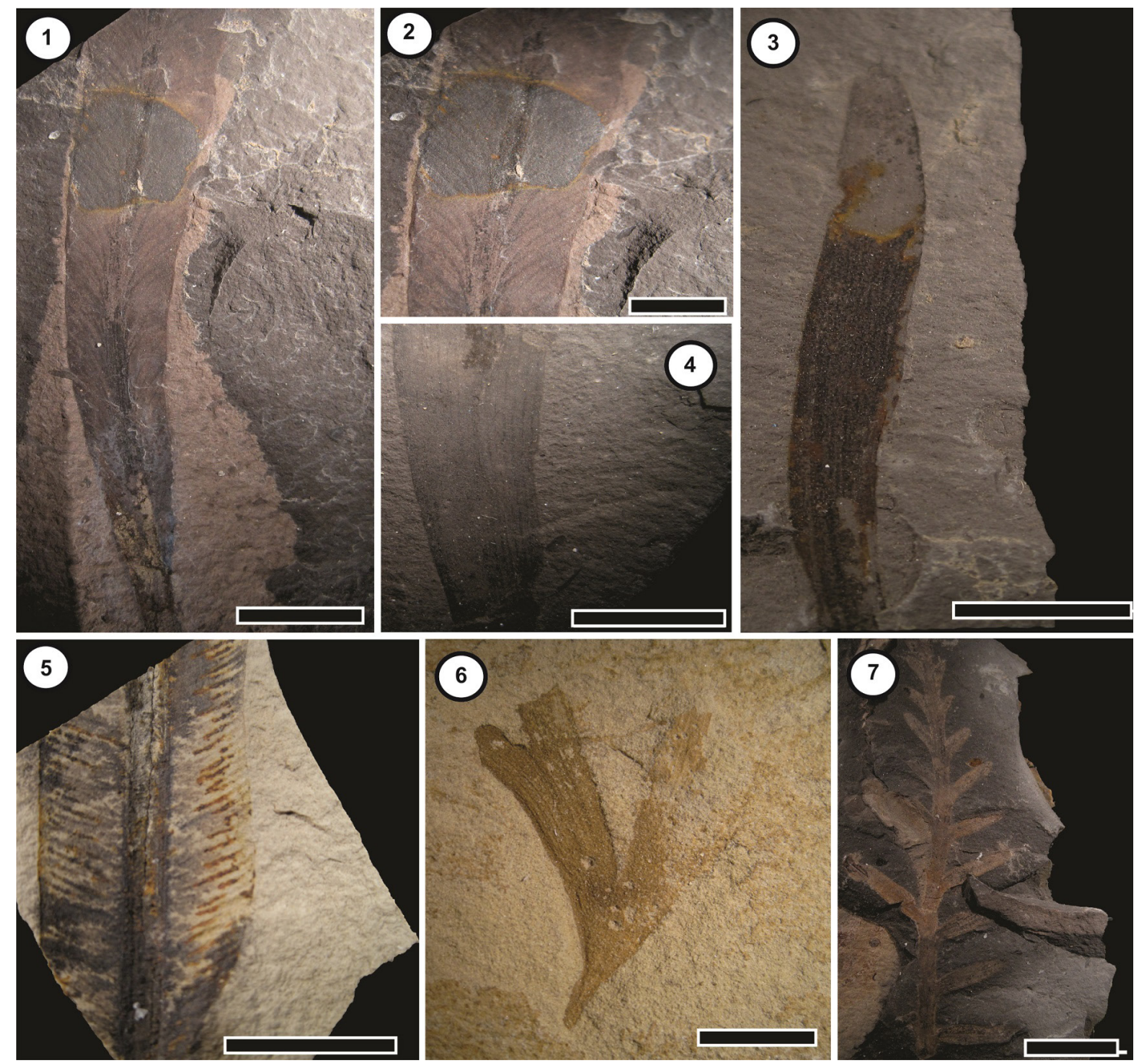

FIG. 4. 1-2. Linguifolium patagonicum. Gnaendinger \& Herbst 1998. IANIGLA-PB-727.Scale bar=1cm. 3-4. Heidiphyllum elongatum Retallack 1981. IANIGLA-PB-716 y 711. Scale bar=1cm.5. Taeniopteris sp. Brongniart 1828. IANIGLA-PB-711 Scale bar=1cm. 6. Sphenobaiera sp. Florin, 1936. IANIGLA-PB-715. Scale bar=1cm. 7. Rissikia media Townrow, 1967. IANIGLA-PB-723. Scale bar $=1 \mathrm{~cm}$.

Comments. Heidiphylum elongatum is characterized by possess apetiolate, linear-eliptical to linear-oblanceolate leaves with entire margins, apex subacute to rounded and parallel venation only forking at the base of the leaf (Retallack, 1981; Anderson and Anderson 1989). Troncoso et al. (2000) highlights the polymorphic character of this species.

Order Coniferales Engler, 1897

Family Podocarpaceae Endlicher, 1847

Genus Rissikia Townrow, 1967

Type species. Rissikia media (Tenison-Woods)
Townrow, 1967

Rissikia media (Tenison-Woods) Townrow, 1967

Figure 4. 7

Synonymy in Holmes (1982), Anderson and Anderson (1989) and Troncoso et al. (2000)

Description. Compressions and impressions of shoots; $2-6 \mathrm{~cm}$ in length and $0.2 \mathrm{~cm}$ in width; leaves with one single midvein, simple, linear, alternated to subopposite, slightly constricted basally, attached laterally to the axis and separated each other $0.2-0.3 \mathrm{~cm}$. 
Comments. The characteristics of the specimens described herein are consistent with the descriptiction of Townrow (1967). Gymnospermopsida incertae sedis

\section{Genus Linguifolium Arber, 1913 emend. Retallack, 1980 Type species. Linguifolium lilleanum Arber, 1913} Linguifolium patagonicum Gnaendinger and Herbst, $1998 b$

Figure 4. 1,2

Description. The studied material includes compressions and impressions of petiolate, linear-spathulate leaf fragments, up to $8.5 \mathrm{~cm}$ in length, and $1.3 \mathrm{~cm}$ of maximium width; petiole distinctive, $0.2 \mathrm{~cm}$ in width; midvein, $0.1-0.2 \mathrm{~cm}$ in width; lateral veins emerge forming an acute angle $\left(5^{\circ}-15^{\circ}\right)$ to midvein and forkat least one time.

Comments. The Agua de la Zorra Formation specimens show the most critical features of the species described by Gnaedinger and Herbst (1998b).

\section{Genus Cordaicarpus Geinitz, 1862 emend.} Archangelsky, 2000

\section{Type species. Cordaicarpus cordai Geinitz, 1862.} Cordaicarpus sp. A

Figure 5. 1

Description. Ovules/seeds compressions, flattened, oval, $0.6 \mathrm{~cm}$ in width, $0.6 \mathrm{~cm}$ in length; sarcotesta filmy, narrow, surrounding an inner, oval, thick walled body (megasporangium); sarcotesta narrowing to one end (basal chalaza?); micropylar channel not preserved.

Comments. Cordaicarpus sp. A superficially resembles many species of the genus, however, the poor preservation of the studied material hindered its specific designation.

\section{Strobilus sp. A \\ Figure 5. 2}

Description. Compression of an incomplete strobilus?; axis dichotomous, $5 \mathrm{~cm}$ in length and $0.2 \mathrm{~cm}$ in width; cupules? $0.5 \mathrm{~cm}$ in diameter.

Comments. This fossil remain is interptered as a probable megasporophyll fragment, however, the attachment area of cupules? on axis is not clearly distinguishable.

\section{Strobilus sp. B}

Figure 5. 3

Description. Compression of a strobilus fragment of linear shape, bearing spirally arranged megasporophylls; cone units include bract/scales complexes and ovules; bract/ scales complex lobate (it is difficult to discriminate between bract and scale due to preservation), bearing ovules or sterile?; ovules oval-shaped, $0.3 \mathrm{~cm}$ wide, $0.6 \mathrm{~cm}$ length, with peduncle, megasporangium, and integument, $0.1 \mathrm{~cm}$ wide, occassionally recognizable.
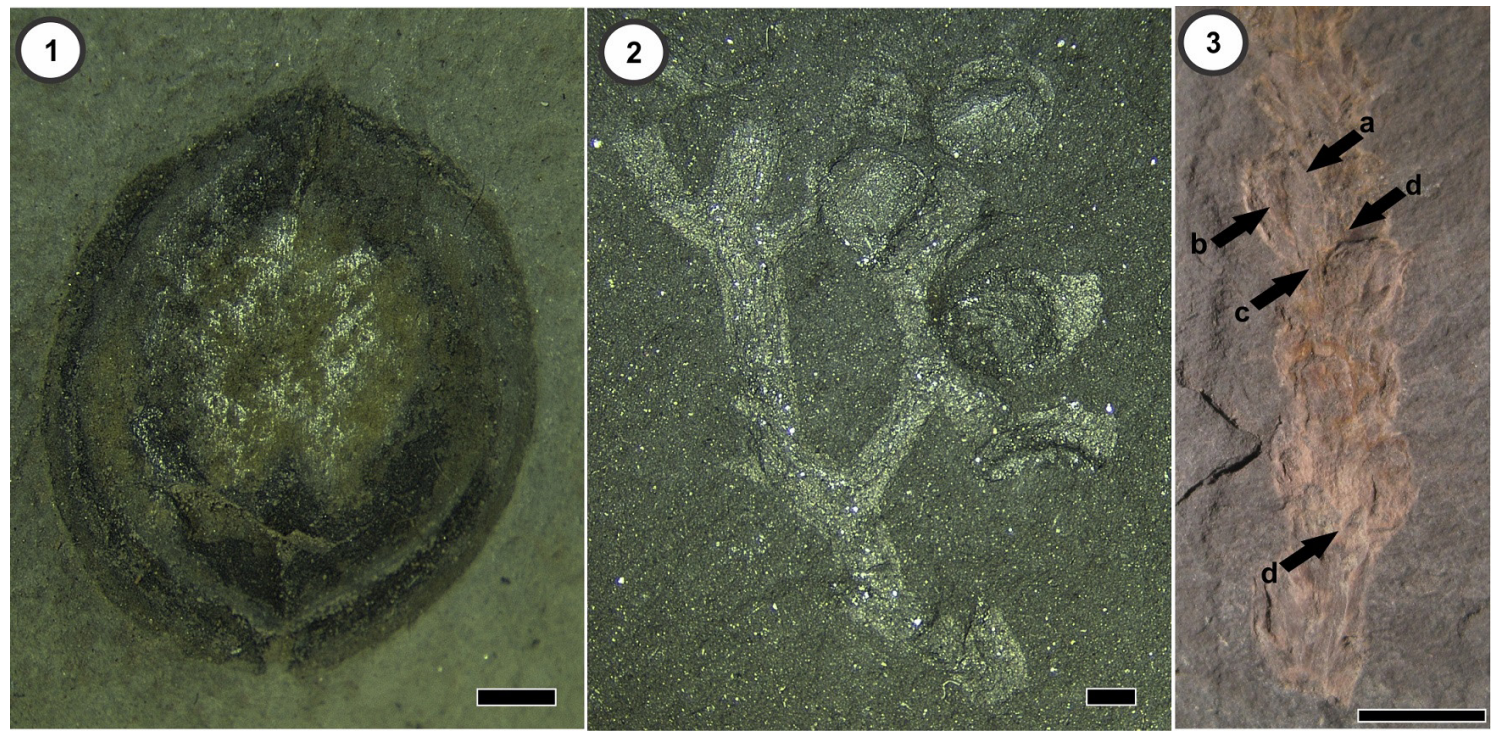

FIG. 5. 1. Cordaicarpus sp. A. IANIGLA-PB-737 Scale bar=1 mm. 2. Strobil.sp. A. IANIGLA-PB-738. Scale bar=1 mm. 3. Strobil sp. B. IANIGLA-PB-722. Scale bar=0.5 cm. a. megasporamgium, b. integument, c. peduncule, $\mathbf{d}$. bractes $/$ scales. 
Comments. Linear-shaped cones bearing megasporophylls of lobed scales were referred by Anderson and Anderson (2003) to Rissikistrobus. Cones of Paleozoic Majonicaceae and Utrechtiaceae (Walchiaceae) also have megasporophylls with lobed scales (Taylor et al., 2009).

\section{Discussion}

The Cuyana Basin is formed by several sub-basin, which due to the lack of continuous outcrops and the scarcity of fossiliferous information, the correlations among their successions have mainly relied on lithostratigraphy and equal distribution of depositional environments (e.g. Yrigoyen and Stover, 1970; Strelkov and Alvarez, 1984; Ramos and Kay, 1991; López-Gamundí and Astini, 2004). In this way, some authors linked all depocenters by lithological similarities and proposed an equivalent infilling history for the whole basin, reflected in the use of a unificated nomenclature (e.g. Yrigoyen and Stover, 1970; Strelkov and Alvarez, 1984; Ramos and Kay, 1991; López-Gamundí and Astini, 2004). However, other authors (e.g. Baldis et al, 1982, Brea et al., 2009; Mancuso et al., 2010; Ottone et al., 2011; Barredo et al., 2012) have considered that separate outcrops represent independent depocenters with a separated geological history, even during the last rifting stage.

Particularly in Mendoza Province, the Potrerillos and Paramillos de Uspallata areas, located in differente sub-basins, include a fluvial-lacustrine susseccion named as Potrerillos-Caheuta and Paramillos-Agua de la Zorra, respectively. Both succesions are chronostratigraphically equivalent constrained to Middle-Upper Triassic based on U-Pb SHRIMP in the Potrerillos Formation (239.2 $\pm 4.5 \mathrm{Ma}$ and 230.3 $\pm 2.3 \mathrm{Ma}$; Spalletti et al., 2008), the U-Pb (LA-ICP-MS) in the Paramillos Formation (239.6 $\pm 1.3 \mathrm{Ma}$; Cingolani et al., 2017), and K/Ar in the Agua de la Zorra Formation ( $235 \pm 5 \mathrm{Ma}$ and $240 \pm 10 \mathrm{Ma}$; Massabie, 1986; Ramos and Kay, 1991; Linares, 2007). In addition, both successions are interpreted as fluvial systems that transitionaly pass to lacustrine environment during the synrift stage (Kokogian et al, 1993, 2001; Spalletti et al., 2005).

The Argentine Triassic megafloras are dominated by the Umkomasiaceae (also know as Corystospermaceae), an endemic Gondwanan family that includes different genera of leaves as Dicroidium, Johnstonia, Xylopteris and Zuberia, but Dicroidium is the most abundant genus in the Triassic paleofloras (Zamuner et al., 2001; Stipanicic and Archangelsky, 2002). The Dicroidium Flora includes also cosmopolitan taxa referred to the Equisetales (Neocalamites, Equisetites), Lycopsida (Pleuromeia),
Osmundales (Cladophlebis), Peltaspermales (Lepidopteris, Scytophyllum), Cycadales (Pterophyllum, Anomozamites, Ctenis, Pseudoctenis, Taeniopteris), Ginkgoales (Ginkgoites, Baiera, Sphenobaiera) and Voltziales (Heidiphyllum) (Zamuner et al., 2001; Stipanicic and Archangelsky, 2002).

As we mentioned previously, only one contribution (Ottone et al., 2011) deal with the systematic study of the Agua de la Zorra Formation paleoflora. On Table 2 we show the relationship between taxa cited for the Agua de la Zorra Formation by Ottone et al. (2011) and taxa described in this contribution.

The megaflora content of the Potrerillos-Cacheuta succession is quite diverse and include more than 100 species

\section{TABLE 2. RELATIONSHIP BETWEEN TAXA CITED FOR AGUA DE LA ZORRA FORMATION AND DESCRIBED THEM IN THIS WORK. *}

\begin{tabular}{|c|c|c|}
\hline Species & $\begin{array}{l}\text { Ottone et al. } \\
\quad(2011)\end{array}$ & $\begin{array}{c}\text { This } \\
\text { contribution }\end{array}$ \\
\hline Neocalamites sp. & $\mathrm{X}$ & $\mathrm{X}$ \\
\hline Cladophlebis kurtzi & & $\mathrm{X}$ \\
\hline C. sp. cf. C. mesozoica & $\mathrm{X}$ & $\mathrm{X}$ \\
\hline Dicroidium argenteum & & $\mathrm{X}$ \\
\hline D. crassum & & $\mathrm{X}$ \\
\hline D. odontopteroides & $\mathrm{X}$ & $\mathrm{X}$ \\
\hline$D$ sp. cf. D. prolungatum & $\mathrm{X}$ & \\
\hline Johnstonia coriacea & & $\mathrm{X}$ \\
\hline J. dutoitii & & $\mathrm{X}$ \\
\hline $\begin{array}{l}\text { J. stelzneriana c.f. J. } \\
\text { serrata }\end{array}$ & $\mathrm{X}$ & $\mathrm{X}$ \\
\hline $\begin{array}{l}\text { J. stelzneriana c.f. J. } \\
\text { stelzneriana }\end{array}$ & $\mathrm{X}$ & \\
\hline Xylopteris elongata & $\mathrm{X}$ & $\mathrm{X}$ \\
\hline$X$. argentina & $\mathrm{X}$ & $\mathrm{X}$ \\
\hline Zuberia feistmanteli & & $\mathrm{X}$ \\
\hline Z. zuberi & & $\mathrm{X}$ \\
\hline $\begin{array}{l}\text { Linguifolium } \\
\text { patagonicum }\end{array}$ & & $\mathrm{X}$ \\
\hline Taeniopteris sp. & & $\mathrm{X}$ \\
\hline Sphenobaiera sp. & & $\mathrm{X}$ \\
\hline Heidiphyllum elongatum & & $\mathrm{X}$ \\
\hline Rissikia media & & $\mathrm{X}$ \\
\hline Cordaicarpus sp A & $\mathrm{X}$ & $\mathrm{X}$ \\
\hline Strobils sp A & & $\mathrm{X}$ \\
\hline Strobils Sp B & & $X$ \\
\hline
\end{tabular}

*Data taken from Ottone et al. (2011). 
(Table 3). They are dominated by the Umkomasiaceae (Dicroidium and Xylopteris), ferns (Cladophlebis) and Equisetales (Neocalamites) (Kurtz, 1921; Stipanicic and Bonetti, 1969; Morel, 1991, 1994; Morel and Artabe, 1993; Brea, 1995, 1997; Brea and Artabe, 1999; Stipanicic et al., 1996; Kokogian et al., 2000; Spalleti et al., 2005). On the other hand, the Paramillos-Agua de la Zorra megaflora assemblage is less diverse and only includes 32 species (Table 3). Conifer (Agathoxylon) and Umkomasiaceous trunks (Cuneumxylon) are common in the Paramillos Formation whilst leaves of Umkomasiaceae (Dicroidium and Xylopteris) and ferns (Cladophlebis) are dominant in the Agua de la Zorra Formation (Darwin, 1846; Conwentz, 1885; Stappenbeck, 1910; Kurtz, 1921; Du Toit, 1927; Groeber, 1939; Windhausen, 1941; Harrington, 1971; Brea and Artabe, 1994, 1999; Brea, 1996a, 1996b, 1997, 2000; Brea et al., 2009; Ottone et al., 2011).
Differences in the taxonomic diversity are markedly evident when comparing the fluvial systems represented by Potrerillos and Paramillos formations (Table 3, Figure 6). The Potrerillos Formation represents a braided fluvial system, which passes upward to moderatelyhigh sinuosity fluvial system with wide development of floodplain and deltaic plain (Kokogian et al. 1993; Zamuner et al., 2001; Spalletti et al., 2005; Lara et al., 2017), and preserves 67 species (Table 3, Fig. 6, Fig. 7.1). The high sinuosity fluvial system, in which channel-filling sand bodies are associated with muddominated floodplain deposits (Brea et al. 2008) of the Paramillos Formation only preserves 10 species (Table 3, Figure 6 and figure 7.1). The differences in the megaflora record could reflect compositional changes in the parental paleocommunity, and/or different environmental and/or preservation conditions.

TABLE 3. RELATIONSHIP BETWEEN TAXA CITED FOR THE POTRERILLOS, CACHEUTA, PARAMILLOS AND AGUA DE LA ZORRA FORMATIONS.*

\begin{tabular}{|c|c|c|c|c|}
\hline Species & Potrerillos Fm. & Cacheuta Fm. & Paramillos Fm. & $\begin{array}{c}\text { Agua de la Zorra } \\
\text { Fm. }\end{array}$ \\
\hline Muscites Guescelini & $\mathrm{X}$ & & & \\
\hline Pleuromeia sp. & $\mathrm{X}$ & $\mathrm{X}$ & $\mathrm{X}$ & \\
\hline Neocalamites carrerei & $\mathrm{X}$ & $\mathrm{X}$ & $\mathrm{X}$ & \\
\hline Neocalamites sp. & & & & $\mathrm{X}$ \\
\hline Neocalamostachys arrondoi & $\mathrm{X}$ & & $\mathrm{X}$ & \\
\hline Nododendron suberosum & $\mathrm{X}$ & & $\mathrm{X}$ & \\
\hline Nododendron sp. & $\mathrm{X}$ & & & \\
\hline Phyllotheca asutralis & $\mathrm{X}$ & & & \\
\hline Phyllotheca gracilis & $\mathrm{X}$ & & & \\
\hline Equisetites fertilis & $\mathrm{X}$ & & & \\
\hline Asterotheca truempyi & $\mathrm{X}$ & & & \\
\hline Cladophlebis copiosa & $\mathrm{X}$ & & & \\
\hline C. kurtzi & $\mathrm{X}$ & $\mathrm{X}$ & $\mathrm{X}$ & $\mathrm{X}$ \\
\hline C. mesozoica & $\mathrm{X}$ & $\mathrm{X}$ & $\mathrm{X}$ & $\mathrm{X}$ \\
\hline C. mendozaensis & $\mathrm{X}$ & $\mathrm{X}$ & $\mathrm{X}$ & \\
\hline Cladophlebis sp. cf. C. mesozoica & & & & $\mathrm{X}$ \\
\hline Cladophlebis sp. & $\mathrm{X}$ & $\mathrm{X}$ & & $\mathrm{X}$ \\
\hline Coniopteris potrerillensis & $\mathrm{X}$ & & & \\
\hline C. harringtonia & $\mathrm{X}$ & & & \\
\hline Lobifolia dejerseyi & $\mathrm{X}$ & & & \\
\hline Glossopteris longicaulis & $\mathrm{X}$ & & & \\
\hline Dicroidium argenteum & $\mathrm{X}$ & & & $\mathrm{X}$ \\
\hline D. crissum & $\mathrm{X}$ & & & $\mathrm{X}$ \\
\hline D. dubium & $\mathrm{X}$ & & & \\
\hline
\end{tabular}


Table 3 continued.

\begin{tabular}{|c|c|c|c|c|}
\hline Species & Potrerillos Fm. & Cacheuta Fm. & Paramillos Fm. & $\begin{array}{c}\text { Agua de la Zorra } \\
\text { Fm. }\end{array}$ \\
\hline D. lancifolium & $\mathrm{X}$ & $\mathrm{X}$ & & \\
\hline D. odontopteroides & $\mathrm{X}$ & $\mathrm{X}$ & & $\mathrm{X}$ \\
\hline$D$ sp. $c f . d$. prolungatum & & & & $\mathrm{X}$ \\
\hline D. pinnis-distantibus & & $\mathrm{X}$ & & \\
\hline Johnstonia coriácea & $\mathrm{X}$ & $\mathrm{X}$ & & $\mathrm{X}$ \\
\hline J. dutoitii & & & & $\mathrm{X}$ \\
\hline J. stelzneriana & $\mathrm{X}$ & $\mathrm{X}$ & & $\mathrm{X}$ \\
\hline Xylopteris elongata & $\mathrm{X}$ & & & $\mathrm{X}$ \\
\hline$X$. argentina & $\mathrm{X}$ & $\mathrm{X}$ & & $\mathrm{X}$ \\
\hline X. spinifolia & & $\mathrm{X}$ & & \\
\hline Zuberia feistmanteli & $\mathrm{X}$ & $\mathrm{X}$ & & $\mathrm{X}$ \\
\hline Z. zuberi & $\mathrm{X}$ & $\mathrm{X}$ & & $\mathrm{X}$ \\
\hline Z. sahinii & & $\mathrm{X}$ & & \\
\hline Umkomasia cacheutensis & & $\mathrm{X}$ & & \\
\hline Umkomasia sp. & $\mathrm{X}$ & & & \\
\hline Pteruchus simmondsi & $\mathrm{X}$ & $\mathrm{X}$ & & \\
\hline Pteruchus sp. & $\mathrm{X}$ & & & \\
\hline Fanerotheca dichotoma & & $X$ & & \\
\hline Feruglioa samaroides & $\mathrm{X}$ & $\mathrm{X}$ & & \\
\hline Cuneumxylon spallettii & $\mathrm{X}$ & & $\mathrm{X}$ & \\
\hline Lepidopteris madagascariensis & $\mathrm{X}$ & & & \\
\hline Pachydermophyllum dubium & $\mathrm{X}$ & & & \\
\hline P. praecordillerae & $\mathrm{X}$ & & & \\
\hline P. pinnatum & $\mathrm{X}$ & & & \\
\hline Antevsia exstans & $\mathrm{X}$ & & & \\
\hline Sphenopteris jocoliensis & $\mathrm{X}$ & & & \\
\hline \multicolumn{5}{|l|}{ Dejerseya lunensis } \\
\hline Lingufolium patagonicum & & & & $\mathrm{X}$ \\
\hline Rochipteris sp. & $\mathrm{X}$ & & & \\
\hline Pseudoctenis falconeriana & & $\mathrm{X}$ & & \\
\hline Kurtziana brandmary & $X$ & & & \\
\hline K. cacheutensis & $\mathrm{X}$ & $\mathrm{X}$ & & \\
\hline Taeniopteris sp. & & & & $\mathrm{X}$ \\
\hline Nilssonia taenipteroides & & $\mathrm{X}$ & & \\
\hline Pterophyllum sp. & & $?$ & & \\
\hline Baiera bidens & $\mathrm{X}$ & & & \\
\hline B. cuyana & $\mathrm{X}$ & & & \\
\hline B. rollerii & $\mathrm{X}$ & & & \\
\hline Sphenobaiera argentinae & $\mathrm{X}$ & $\mathrm{X}$ & & \\
\hline S. taeniata & $X$ & & & \\
\hline
\end{tabular}

* Data taken from Darwin, 1846; Brea and Artabe, 1994, 1999; Brea, 1995, 1996a, 1996b, 1997, 2000; Brea et al., 2009; Ottone et al., 2011 Kutrz, 1902, 1921; Stipanicic and Bonetti, 1969; Stipanicic, 1982; Morel, 1991, 1994; Morel and Artabe, 1993; Morel et al., 2010, 2011; Stipanicic et al., 1996; Kokogian et al., 2000; Spalleti et al., 2005. 


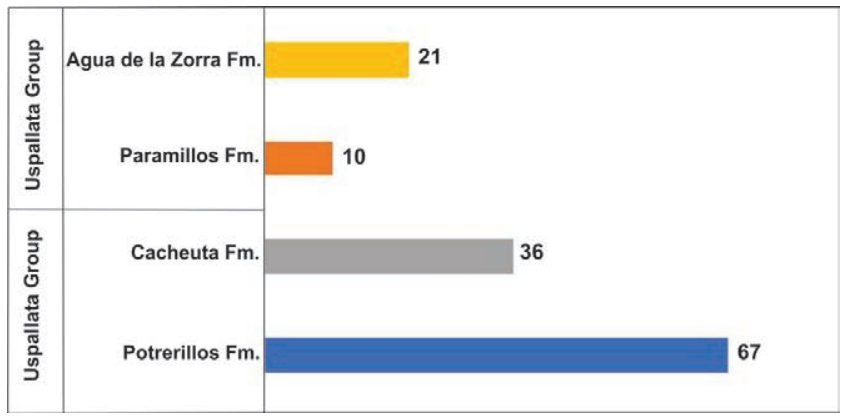

FIG. 6. Number of species in the Potrerillos, Cacheuta, Paramillos and Agua de la Zorra formations of flucial-lacustrine sequence of Cuyana.

(1)

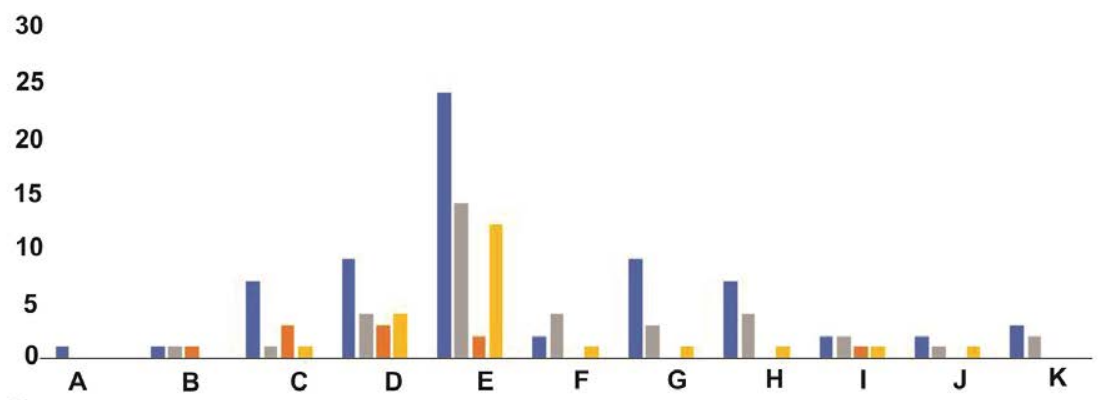

(2)

30

25

20

15

10

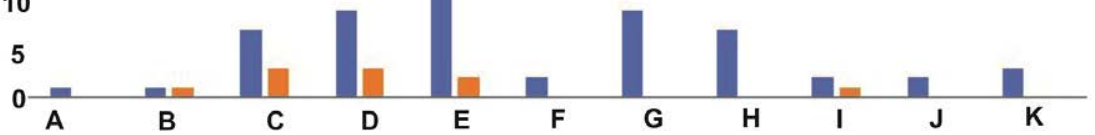

(3)

16

14

12

10

8
6

4

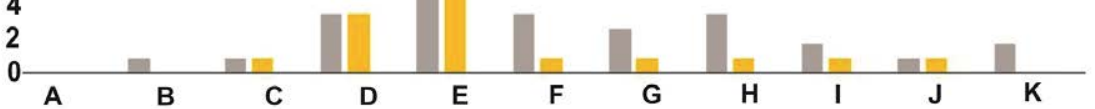

A

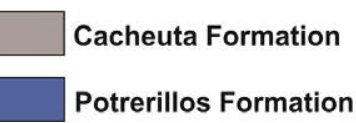

Agua de la Zorra Formation

Paramillos Formation

FIG. 7. 1. Number of species for taxonomic groups in the Potrerrillos, Cacheuta, Paramillos and Agua de la Zorra formations. 2. Comparison between the number of species registered in the Potrerillos and Paramillos formations. 3. Comparison between the number of species registered in Cacheuta and Agua de la Zorra formations. References. A: Briofitas, B: Isoetales, C: Equisetales, D: Filicales, E: Pteridospermales, F: Cycadales and Cycadeoideas, G: Ginkgoales and Czekanowskiales, H: Voltziales, I: Coniferales, J: Gimnospermosidas I.S., K: Gnetales. 
Plants have a limited number of potential depositional sites, and plant preservation is restricted by the sediment supply rate, accommodation space, and groundwater fluctuation, therefore depend on the tectonic and climatic conditions (Behrensmeyer and Hook, 1992; Spicer, 1991; Demko et al., 1998; Gastaldo et al., 2005; Gastaldo and Demko, 2011). The Potrerillos and Paramillos fluvial systems show a well-developed flood plain in relatively few channel belts reflecting that the generation of accommodation space was at least equal to the rate of sediment supply. The Potrerillos megaflora was mainly composed of leaves preserved as carbonaceous compressions and/or impressions (Morel et al., 2010, 2011), related to the floodplain and crevasse splay (Zamuner et al., 2001; Spalletti et al., 2005; Lara et al., 2017). A relatively high groundwater position enhance the preservation potential of plant remains (Retallack, 1984). The abundance and diversity of the Potrerillos Formation fossil plants could reflect similar characters of the original flora, but also rely in the presence of a high position to the water table. The Paramillos Formation preserved an in situ fossil forest (Darwin Forest) developed on a volcaniclastic floodplain (Darwin, 1846; Brea and Artabe, 1994, 1999; Brea, 1996a, 1996b, 1997, 2000; Brea et al., 2009; Ottone et al., 2011). Sedimentological evidences (sediment supply and accommodation space) suggest similar condition of depositation than in the Potrerillos Formation, however the poor preservation of leaves would suggest the existence of a potential fluctuated groundwater.

The Potrerillos and Paramillos fluvial successions were influenced by volcanism that affected the southwest Gondwana margin during the Permo-Triassic. The Potrerillos Formation recorded several tuff and tufaceous sandstones (which were used to obtain absolute age for the unit). The Paramillos Formation included tuff and tufaceous sandstone but also basalt flows (Massabie, 1986; Ramos and Kay, 1991; Poma et al., 2009, Cingolani et al., 2017). Moreover, the Darwin Forest seems to be buried by a diluted, subaerial, cool and wet base surge pyroclastic flow (Brea et al., 2008).

Volcanism produces disruption in the surrounding environments with negative effect in plant biodiversity, and changes in the physical-chemical conditions into sedimentary environment. In consequence, vegetation affected by volcanism (debris flows, pyroclastic flows, lahars, air-fall tephra, lava flows) suffers a catastrophic devastation (Behrensmeyer and Hook, 1992; Spicer, 1991; Dale et al., 2005) and the dynamics of the fluvial and lacustrine systems are disrupted.

A volcanic explosion is considered as an ecological disruption (White and Pickeett, 1985; Dale et al.,
2005), and the process of gradual ecological change after disturbance is named succession (Thoreau, 1993). Primary succession is the ecological restoration process in entirely denuded areas and cleansed of biota, as occur in areas affected by lava flow (Dale et al., 2005). In the forest cases, the succession can may take thousands of years (e.g., Grishin et al. 1996). Post-eruption, the soil is deeply disturbed by ash fall, pyroclastic flow, and/or lava flow (LaManna and Ugolini, 1987). The ecological succession of the vegetal communities must be adapted to the new stressed post-eruption conditions. Thus, the ecological restoration in the first stage in the succession will be very slow, show low taxonomic diversity, poor development of biomass and communities of limited structural complexity (Del Moral and Wood, 1993; Dale et al. 2005). The low diversity and abundance recorded at the Paramillos Formation could be related with the first stage of post-eruption ecological succession. Besides, in the first stage of the ecological succession opportunist, generalist, fast growing, r-strategist species, generally ferns, dominated the community (Spicer, 1991), a kind of herbaceous plants that require specific conditions (low energy, anoxia or disoxya) to preserve.

In contrast to fluvial systems of Potrerillos and Paramillos, the lacustrine systems represented by Cacheuta and Agua de la Zorra formations show almost the same taxonomic diversity (Table 3, Figure 7.2). The Cacheuta Formation preserve 36 species, whereas the Agua de la Zorra Formation 22 species (Table 3, Fig. 6), both in deep lacustrine systems. Despite of the taxonomic diversity is similar, the number of genera in different taxa are quite variable (Fig. 7.1). The Cacheuta taphoflora is dominated by different species of Dicroidium with subordinate ferns (Cladophlebis) (Table 3) and the Agua de la Zorra tafoflora is dominated by fronds of Umkomasiaceae (Dicroidium and Xylopteris), ferns as (Cladophlebis) and Equisetales (Neocalamites) (Table 2, Figure 7.3).

Both Cacheuta and Agua de la Zorra lacustrine systems are characterized by the development of deep offshore facies, with anoxic bottom and delta progradation in the lacustrine facies (Spalletti et al., 2005; Ottone et al., 2011, Pedernera et al., 2016, 2017). Furthermore, both succession recorded volcanic rocks, tuff and tufaceous sandstones levels in Cacheuta and tuff and tufaceous sandstone, sills and basalt flows (which were used to obtain absolute age for the unit) in Agua de la Zorra (Massabie, 1986; Ramos and Kay, 1991, Linares 2007). The peperitic beds interbedded in the Agua de la Zorra lacustrine facies, currently interpreted as basaltic lava flow episodic incursion in the water body is a main difference between both secessions (Ottone et al., 2011). 
In both Cacheuta and Agua de la Zorra successions, the presence of a high water table that enhanced the preservation potential of vegetal elements is evident. Both lacustrine successions are dominated by laminated bituminous mudrocks related to offshore facies, and include carbonaceous compressions of disarticulated, isolated, fragmented simple or compound leaves (Morel, 1994, 2010, 2011; Ottone et al., 2011; Pedernera et al., 2016). When more distal is the Cacheuta and Agua de la Zorra delta facies, more variable is the size, and higher the articulation degree, density package, and preferential orientation of vegetal remains (Pedernera et al., 2016). In the case of Agua de la Zorra, the main specimens recovered in these facies are related to Umkomasiaceae compound leaf remains referred to Xylopteris (Figure 8). Lacustrine anoxic bottoms are environments where the rate of decay and/or biodegradation of plant remains are significantly lower than that in the oxygenated environments. Thus, a lacustrine anoxic bottom enhances the preservation of organic plant remains (Behrensmeyer and Hook, 1992, Spicer, 1991; Gastaldo and Demcko, 2011). However, the amount of plant remains that arrived to the lake offshore by flotation or dispersion are less numerous than those preserved in areas closer to the coast or with deltaic influence (Spicer, 1991). Therefore, the relative abundance of plant remains in offshore facies does not reflect the diversity of the plant paleocommunities associated with the lacustrine systems. In contrast, in the oxigenated delta and marginal palustrine environments, where there is a consequently higher rate of decay, the preservation potential would be linked to factors as the rate of sediment supply or the water table fluctuation (Retallack 1984; Behrenseyer and Hook, 1992; Spicer, 1991; Gastaldo and Demcko, 2011).

Lacustrine systems influenced by volcanism present increase in the rate of sediment supply linked with unusual ash fall supply, which also triggers changes in the original chemical composition of lake waters (Behrensmeyer and Hook, 1992; Spicer, 1991). Ash fall also plays a major role in plant preservation; the ash layers restrict oxygen and limit the action of detritivores, that are buried rapidly, preserving delicate plant remains (Burnham and Spicer, 1986; Spicer, 1991).

The Cacheuta Formation includes tuff levels and the Agua de la Zorra Formation also includes peperitic basalts (Ottone et al., 2011). The peperite levels resulted by interaction between lava and water/sediment, the basalts disturbed the sedimets of the bottom of the lake but sediments and plant remains entombed therein remained termally unaffected (Ottone et al., 2011). The evidences of alteration produced by temperature of the basalts in the sediments and plant remains (both micro- and macro-remains) are not present in all the sections studied. Therefore, the shift in diversity in the tafofloras of the Cacheuta and Agua de la Zorra taphoflora can be mainly related to ecological differences than variations in the taphonomic processes in each of the lake systems (Table 3 ).

\section{Conclusions}

The systematic study of a taphoflora recovered from the Agua de la Zorra includes 21 taxa, 12 of them referred in the unit by the first time (one species of the fern leave Cladophlebis; two species of Dicroidium, two species of Johnstonia, and two species of Zuberia, all Umkomasiaceae leaves; the cycadalean Taeniopteris; the ginkgoalean Sphenobaiera; conifers as Heidiphyllum, and Rissikia; together with other gymnosperms as Linguifolium, strobils and ovules/seeds).

The comparison of the chronostratigraphically equivalent Middle-Upper Triassic taphofloras influenced by the active volcanism from southwest of Gondwana margin, shows clear differences. The Paramillos and Potrerillos taphoflora, both related to fluvial environments, are markedly different in taxonomic diversity, due mainly to preservation potential linked to groundwater position that in Potrerillos was high enhancing the plant preservation and in Paramillos was fluctuated resulted in a poor preservation of leaves. Moreover, the low diversity and abundance recorded in the beginning of the Paramillos post-eruption, ecological succession can explain the scarcity of the taphoflora. The Cacheuta and Agua de la Zorra taphoflora show a similar taxonomic diversity in spite of the Agua de la Zorra lacustrine systems are affected by basaltic lava flow episodic incursions in the water body. These disturbed basalts unaffected sediments and plant remains entombed in the bottom of the lake. The differences are an effect of variation in the ecological paleocommunities.

\section{Aknowledgements}

The authors wish to thanks to E.L. Bustos Escalona and C. Sancho for they support during the fieldstrips. We thanks to A.B. Arcucci, María de los Angeles Goméz and E. Previtera for the critical reading of the manuscript and they constructive comments. We are also grateful to $\mathrm{M}$. Brea and J. Bodnar for their critical review of the submitted manuscript. This research was supported by grants PICT2013-0805 (Agencia Nacional de Promoción Científica y Tecnológica) and PIP 112-201501-00613-CONICET (Consejo Nacional de Investigaciones Científicas y Técnicas). This is the contribution R-278 of the Instituto de Estudios Andinos Don Pablo Groeber. 


\section{References}

Albanesi, G.L.; Johns, M.; Voldman, G.G. 2009. Fresh-water shark teeth from the Triassic Paramillo Formation in the Mendoza Precordillera, Argentina. Ameghiniana, Suplemento Resúmenes 46: 14R.

Anderson, J.M.; Anderson, H.M. 1970. A preliminary review of the uppermost Permian, Triassic and lowermost Jurassic of Gondwanaland. Palaeontologia Africana 13, Supplement: 1-22.

Anderson, J.M.; Anderson, H.M. 1983. Palaeoflora of Southern Africa Molteno Formation (Triassic). Volume 1. Part 1. Introduction/Part 2. Dicroidium. A.A. Balkema: 227 p. Rotterdam.

Anderson, J.M.; Anderson, H.M. 1989. Palaeoflora of Southern Africa Molteno Formation (Triassic). Volume 2. Gymnosperms (excluding Dicroidium). A.A. Balkema: 567 p. Rotterdam.

Anderson, J.M.; Anderson, H.M. 2003. Heyday of the gymnosperms: systematic and biodiversity of the Late Triassic Molteno fructifications. Sterlitzia 15 (8): 398 p. Pretoria.

Andreanszky, G. 1954. Andreanszky Osnovenytan Akademia Kiado: 263 p., Budapest.

Arber, E. 1913. A preliminary note on the fossil plants of the Mt. Potts Beds, New Zealand, collected by Mr. D.G. Lillie biologist to Captain Scots Atarctic Expedition in the "Terra Nova". Proceedings of the Geological Society of London 86B: 344-347. London.

Archangelsky, A. 2000. Estudio sobre semillas neopaleozoicas de Argentina. Boletín de la Academia Nacional de Ciencias 64: 79-115.

Archangelsky, S. 1968. Studies on Triassic fossil plants from Argentina. 4. The leaf genus Dicroidium and its possible relation to Rhexoxylon stems. Palaeontology 11: 500-512.

Arnold, C.A. 1947. An Introduction to Paleobotany McGraw-Hill Book Company: 433. New York.

Artabe, A.E. 1985. Estudio sistemático de la tafoflora triásica de Los Menucos, provincia de Río Negro, Argentina. Parte 1. Sphenophyta, Filicophyta, Pteridospermophyta. Ameghiniana 22: 3-22.

Artabe, A.E. 1990. Revalidación del género triásico Zuberia Frenguelli 1943, Familia Corystospermaceae. Revista del Museo de La Plata (nueva serie) 9, Paleontología 55: 45-157.

Artabe, A.E.; Morel, E.M.; Ganuza, D.G. 2007. Las floras triásicas de la Argentina. Asociación Paleontológica Argentina, Publicación Especial 11: 75-86.
Baldis, B.A.; Beresi, M.; Bordonaro, O.; Vaca, A. 1982. Síntesis evolutiva de la Precordillera Argentina. In Congreso Latinoamericano de Geología, No. 5, Actas, 4: 399-445.

Barboni, R.; Dutra, T.L.; Faccini, U.F. 2016. Xylopteris (Frenguelli) Stipanicic and Bonetti in the MiddleUpper Triassic (Santa Maria Formation) of Brazil. Ameghiniana 53: 599-622.

Barredo, S.; Chemale, F.; Marsicano, C.; Ávila, J.N.; Ottone, E.G.; Ramos, V.A. 2012. Tectono-sequence stratigraphy and $\mathrm{U}-\mathrm{Pb}$ zircon ages of the Rincón Blanco Depocenter, northern Cuyo Rift, Argentina. Gondwana Research 21 (2-3): 624-636.

Behrensmeyer, A.K.; Hook, R.W. 1992. Paleoenvironmental contexts and taphonomic modes in the terrestrial fossil record. In The evolutionary paleoecology of terrestrial plants and animals (Behrensmeyer, A.K.; Damuth, J.D.; DiMichele, W.A.; Potts, R.; Sues, H.D.; Wing, S.L.; editors). University of Chicago Press: 15-136.

Bodenbender, G. 1911. Constitución geológica de la parte meridional de La Rioja y regiones limítrofes. Boletín de la Academia Nacional de Ciencias 19: 5-221.

Bonetti, M.I.R. 1966. Consideraciones sobre algunos representantes de la familia Corystospermaceae. Ameghiniana 4: 389-395.

Boureau, E. 1964. Traité de Paléobotanique, 3 Sphenophyta, Noeggerathiophyta. Masson et Cie.: 544 p. Paris.

Boureau, E.; Doubinger, J. 1975. Traité de Paléoboatanique. Pteridophylla ( $1^{\mathrm{a}}$ partie). Ed. Boureau et J. Doubinger. Masson: $768 \mathrm{p}$.

Brea, M. 1995 Estudio de la paleoflora de la secuencia triásica de Agua de la Zorra, provincia de Mendoza. Universidad Nacional de La Plata, Tesis Doctoral (Inédito) 642: 202 p.

Brea, M. 1996a. Estudio sedimentológico, paleoecológico y paleobotánico de la Formación Paramillo (Triásico), Agua de la Zorra, Mendoza. Ameghiniana 33: 229.

Brea, M. 1996b. Una nueva especie triásica de Araucarioxylon de la Formación Paramillo, Agua de la Zorra, provincia de Mendoza. Ameghiniana 33: 229.

Brea, M. 1997. Una nueva especie del género Araucarioxylon Kraus 1870, emend. Maheshwari 1972 del Triásico de Agua de la Zorra, Uspallata, Mendoza, Argentina. Ameghiniana 34: 485-496.

Brea, M. 2000. Paleoflora triásica de Agua de la Zorra, Uspallata, provincia de Mendoza, Argentina: Lycophyta y Filicophyta. Ameghiniana 37: 199-204.

Brea, M.; Artabe, A.E. 1994. Una nueva especie de Neocalamostachys Kon'no, 1962 en el Triásico de Mendoza, Argentina. Ameghiniana 31: 395. 
Brea, M.; Artabe, A.E. 1999. Apocalamitaceae (Sphenophyta) triásicas de la Formación Paramillo, Agua de la Zorra, provincia de Mendoza, Argentina. Ameghiniana 36: 389-400.

Brea, M.; Artabe, A.; Spalletti, L.A. 2006. Estructura de un bosque mixto del Triásico Medio de Mendoza, Argentina. In Congreso Argentino de Paleontología y Bioestratigrafía, No. 9, Resúmenes: 241. Córdoba.

Brea, M.; Artabe, A.; Spalletti, L.A. 2008. Ecological reconstruction of a mixed Middle Triassic forest from Argentina. Alcheringa 32: 365-393.

Brea, M.; Artabe, A.E.Spalletti, L.A. 2009. Darwin Forest at Agua de la Zorra: the first in situ forest discovered in South America by Darwin in 1835. Revista de la Asociación Geológica Argentina 64: 21-31.

Brongniart, A. 1828. Histoire des végétaux fossiles ou recherché botaniques et géologiques sur les végétaux renfermés dans les diverses couches du globe. Tome Premier. G. Dufour and E. d'Ocagne: 488 p. Paris.

Brongniart, A. 1849.Tableau des genres de végétaux fossiles considérés sous le point de vue de leur classification botanique et de leur distribution géologique (Extrait du Dictionnaire universel d'Histoire naturelle). L. Martinet: 127 p. Paris.

Burnham, R.J.; Spicer, R.A. 1986. Forest litter preserved by volcanic activity at El Chichon, Mexico: A potentially accurate record of the pre-eruption vegetation. Palaios, 158-161.

Candolle, A.P. 1804. Essai sur les propriétésmédicales des plantes, comparées avec leursformesextérieures et leur classification naturelle. Didot Jeune: 148 p. Paris

Carrizo, M.A.; Del Fueyo, G.M.; Archangelsky, S. 2011. Morfología y anatomía de un helecho creciendo bajo condiciones de estrés en el Aptiano de Santa Cruz, Argentina. Ameghiniana 48: 605-617.

Carruthers, W. 1872. Notes on fossil plants from Queensland, Australia. Proceedings of the Geological Society of London: 350-359.

Césari, S.N.; Párica, C.; Remesal, M. and Salani, F. 1998. First evidence of Pentoxylales in Antarctica. Cretaceous Research 19: 733-743.

Cingolani, C.A.; Uriz, N.J.; Basei, M.A.S. 2017. La datación U-Pb del evento volcanigénico Triásico de Agia de la Zorra-Paramillos, Uspallata, Mendoza. In Congreso Geológico Argentino, No. 20: 16-21. Tucuman.

Cleal, C.J.; Rees, P.M., 2003. The Middle Jurassic flora from Stonesfield, Oxfordshire, UK. Palaeontology 46: 739-801.
Conwentz, H. 1885. Sobre algunos árboles fósiles del Río Negro. Boletín de la Academia Nacional de Ciencias, 7: 435-456. Córdoba.

Cortés, J.M.; González Bonorino, G.; Koukharsky, M.L. 1997. Hoja Geológica 3369-09 Uspallata. Provincia de Mendoza. República Argentina. Programa Nacional de Cartas Geológicas de la República Argentina 1:100.000. Servicio Geológico Minero Argentino, Boletín 281 (Inédito): $160 \mathrm{p}$.

Cronquist, A.; Takhtajan, A.; Zimmermann, W. 1966. On the higher taxa of Embryobionta. Taxon 15: 129-134.

Dale, V. H.; Swanson, F. J.; Crisafulli, C. M. 2005. Disturbance, survival, and succession: understanding ecological responses to the 1980 eruption of Mount St. Helens. In Ecological responses to the 1980 eruption of Mount St. Helens, Springer: 3-11. New York.

Darwin, C. 1846. Geological observations on South America. Being the third part of the geology of the voyage of the Beagle, under the command of Capt. FitzRoy, R.N. during the years 1832 to 1836 . Smith, Elder \& Co., London, vii, 279 p.

de Candolle, A.P. 1804. Essai sur les propriétés médicales des plantes, comparées avec leurs formes extérieures et leur classification naturelle. Didot Jeune: 148 p. Paris

Del Moral, R.; Grishin, S. Y. 1999. Volcanic disturbances and ecosystem recovery. Ecosystems of the world, 137-160.

Del Moral, R.; Wood, D. M. 1988. Dynamics of herbaceous vegetation recovery on Mount St. Helens, Washington, USA, after a volcanic eruption. Vegetatio 74: 11-27.

Del Moral, R.; Wood, D. M. 1993. Early primary succession on the volcano Mount St. Helens. Journal of Vegetation Science 4 (2): 223-234.

Demko, T.M.; Dubiel, R.F.; Totman Parrish, J. 1998. Plant taphonomy in incised valleys: implications for interpreting paleoclimate from fossil plants. Geology, 26 (12): 1119-1122.

Doweld, A.B. 2017. (2560) Proposal to conserve the name Umkomasiaceae against Zuberiaceae (fossil Peltaspermophyta: Umkomasiales). Taxon 66 (5): 1231-1232.

Du Toit, A.L. 1927. A geological comparison of South America with South Africa. Carnegie Institution Publication 381: 158 p.

Dumortier, B.C. 1829. Analyse des familles de plantes, avec l'indication des principaux genres qui s'y rattachent. Imprimerie de J. Casterman Ainé: 104 p. Tournay. 
Dunker, W.B.R.H. 1846. Monographie der norddeutschen Wealdenbildung. Ein Beitrag zur Geognosie und Naturgeschichte der Vorwelt, Oehme und Muller, Braunschweig, xxxii, $83 \mathrm{p}$.

Elgorriaga, A.; Escapa, I.H.; Rothwell, G.W.; Tomescu, A.M.; Rubén Cúneo, N. 2018. Origin of Equisetum: Evolution of horsetails (Equisetales) within the major euphyllophyte clade Sphenopsida. American Journal of Botany 105 (8): 1286-1303.

Endlicher, S. 1847. Synopsis Coniferarum. Schleitin and Zollikofer, Sangalli, iv, 368 p.

Engler, H.G.A. 1897. Die natürlichen Planzenfamilien nebst ihren Gattungen und wichtigeren Arten insbesondere den Nutzpflanzen unter Mitwirkung zahlreicher herborragender Fachgelehrten. Nachträge zum II-IV Teil. Wilhem Engelmann: 380 p. Leipzig.

Escapa, I.H.; Cúneo, R.N. 2004. Primer registro de Neocalamites (Halle) Vladimirovicz en el Pérmico de Gondwana. Ameghiniana 43: 85-92.

Florin, R.1936. Die fossilen Gingkophyten aus FranzJoseph-Land nebst Erörterungen über vermeintliche Cordaitales mesozoischen Alters. I. Spezieller Teil. Palaeontographica, Abteilung B81: 71-173.

Frenguelli, J. 1943. Reseña crítica de los géneros atribuidos a la "Serie de Thinfeldia". Revista del Museo de La Plata (nueva serie) 2, Sección Paleontología 12: 225-342.

Frenguelli, J. 1944. Las especies del género "Zuberia" en la Argentina. Anales del Museo de La Plata (nueva serie) Paleontología: Sección B, Paleobotánica 2, Pteridofitas yPteridospermas 1: 1-30.

Frenguelli, J. 1947. El género "Cladophlebis" y sus representantes en la Argentina. Anales del Museo de La Plata, nueva serie, Paleontología: Sección B; Paleobotánica 2. Pteridofitas y Pteridospermas 2: 74 p. La Plata.

Gastaldo, R.A.; Demko, T. M. 2011. The relationship between continental landscape evolution and the plant-fossil record: long term hydrologic controls on preservation. in Taphonomy (Springer): 249-285. Netherlands.

Gastaldo, R.A.; Adendorff, R.; Bamford, M.; Labandeira, C.C.; Neveling, J.; Sims, H. 2005. Taphonomic trends of macrofloral assemblages across the Permian-Triassic boundary, Karoo Basin, South Africa. Palaios 20 (5): 479-497.

Geinitz, H.B. 1862. Dyas oder die Zechsteinformation und das Rothliegende. Mit Beiträgen von R. Eisel, R. Ludwig, A.E. Reuss, R. Richter u.a. H. Die Pflanzen der Dyas und Geologisches. Wilhem Engelmann, Leipzig, VIII, 131-342.
Geinitz, H.B. 1876. Ueber Rhätische Pflanzen- und Thierreste in den argentinischen Provinzen La Rioja, San Juan und Mendoza. In Stelzner, A.; editors. Beiträge zur Geologie und Palaeontologie der Argentinischen Republik. 2. Paläontologischer Theil. Palaeontographica, Supplementbände 3, Cassel, p. 1-14.

Gnaedinger, S.; Herbst, R. 1998a. La flora triásica del Grupo El Tranquilo, provincia de Santa Cruz (Patagonia). Parte 4. Pteridospermae. Ameghiniana 35: 33-52.

Gnaedinger, S.; Herbst, R 1998b. La flora triásica del Grupo El Tranquilo, provincia de Santa Cruz (Patagonia). Parte V Pteridophylla Ameghiniana 35: 53-65.

Gnaedinger, S.; Herbst, R. 1999. La flora Triásica del Grupo El Tranquilo, provincia de Santa Cruz, Patagonia. Parte VI: Ginkgoales. Ameghiniana 36: 281-296.

Gnaedinger, S.; Herbst, R. 2001. Pteridospermas triásicas del Norte Chico de Chile. Ameghiniana 38: 281-298.

Good, C. W. 1975. Pannsylvanean-age calamitean cones, elater bearing spores, and associated vegetative organs. Palaeontographica, Abteilung B 159: 28-99.

Goroschankin, I.N. 1904. Lectures on the morphology and systematic of the archeogoniate plants. II. Pteridophyte and Archispermae. Tovaristshetva Tipografii A.I. Mamonova, Moscow.

Gothan, W. 1912. Über die Gattung Thinnfeldia Ettinghausen. Abhandlungen Naturhistorischen Gesellschaft 9: 67-80.

Grishin, S. Y.; del Moral, R.; Krestov, P. V.; Verkholat, V. P. 1996. Succession following the catastrophic eruption of Ksudach volcano (Kamchatka, 1907). Vegetatio, 127 (2): 129-153.

Groeber, P. 1939. Mapa geológico de Mendoza. Physis 14: 171-220.

Groeber, P.; Stipanicic, P. 1952. Triásico. In Geografía de la República Argentina. Tomo II. Primera Parte (Groeber, P.; editor). Sociedad Argentina de Estudio Geográficos GAEA, Buenos Aires, p. 13-141.

Halle, T.G. 1908. Zur Kenntnis der Mesozoischen Equisetales Schwedens. Kunglinga Svenka Vetenskapsakademiens Handligar 43: 1-57.

Harrington, H.J. 1971. Descripción geológica de la Hoja 22c, Ramblón. Servicio Nacional Minero Geológico. República Argentina, Ministerio de Industria y Minería, Subsecretaría de Minería.

Harris, T.M.; Millington, W.; Miller, J. 1974. The Jorkshire Jurassic Flora IV. 1 Ginkgoales. 2 Czekanowskiales. The British Museum (Natural History) IX: 150 p. London.

Herbst, R. 1971. Palaeophytologia Kurtziana. III. 7. Revisión de las especies argentinas del género Cladophlebis. Ameghiniana 8: 265-281. 
Holmes, W.B.K.; Ash, S.R. 1979. An Early Triassic megafossil flora from the Lorne Basin, New South Wales. Proceedings of the Linnean Society of New South Wales 103: 47-70.

Johnston, R.M. 1886. Fresh contribution to our knowledge of the plants of Mesozoic age in Tasmania. In Papers and Proceedings of the Royal Society of Tasmania: 160-183.

Kenrick, P.; Crane, P.R. 1997. The origin and early diversification of land plants. A cladistic study. Smithsonian Institution Press, XIV, 441 p. Washington.

Kokogian, D.A.; Fernández Seveso, F.; Mosquera, A. 1993. Las secuencias sedimentarias triásicas. In Congreso Geológico Argentino 12: 65-78. Mendoza.

Kokogián, D.A.; Spalletti, L.A.; Morel, E.M.; Artabe, A.E.; Martínez, R.N.; Alcober, O.A.; Milana, J.P.; Zavattieri, A.M.; Papú, O.H. 2000. Los depósitos continentales triásicos. In Geología Argentina (Caminos, R.; editor). Instituto de Geología y Recursos Minerales, Anales 29: 377-398. Buenos Aires.

Kokogian, D.A.; Spalletti, L.A.; Morel, E.M.; Artabe, A. E.; Martínez, R.N.; Alcober, O.A.; Papú, O. 2001. Estratigrafía del Triásico argentino. El Sistema Triásico en la Argentina. Fundación Museo de La Plata "Francisco Pascasio Moreno": 23-54 p. La Plata.

Kurtz, F. 1921. Atlas de plantas fósiles de la República Argentina. Academia Nacionalde Ciencias de Córdoba, Actas 7: 129-153.

LaManna, J.M.; Ugolini, F.C. 1987. Trioctahedral vermiculite in a 1980 pyroclastic flow, mt. St. Helens, Washington. Soil Science 143 (3): 162-167.

Lara, M.B.; Cariglino, B.; Zavattieri, A.M. 2017. Palaeoenvironmental interpretation of an Upper Triassic deposit in southwestern Gondwana (Argentina) based on an insect fauna, plant assemblage, and their interactions. Palaeogeography, Palaeoclimatology, Palaeoecology 476: 163-180.

Linares, E. 2007. Catálogo de edades radimétricas de la República Argentina años 1957-2005. Asociación Geológica Argentina, Buenos Aires, Serie "F" (Publicaciones en CD) 2: $11 \mathrm{p}$.

Lindenmayer, D. B.; Likens, G. E.; Franklin, J. F. 2010. Rapid responses to facilitate ecological discoveries from major disturbances. Frontiers in Ecology and the Environment 8 (10): 527-532.

Linnaeus, C.A. 1771. Mantissa Plantarum. Holmiae.

Link, H.F. 1833. Hortius regius botanicus Berolinensis. Tomus II. G. Reimer, Berlin: 376 p.

López-Gamundí, O. R.; Astini, R. A. 2004. Alluvial fan-lacustrine association in the fault tip end of a half-graben, northern Triassic Cuyo basin, western
Argentina. Journal of South American Earth Sciences 17 (4): 253-265.

Lutz, A.; Gnaedinger, S.; Mancuso, A.; Crisafulli, A. 2011. Paleoflora de la Formación Los Rastros (Triásico Medio), provincia de San Juan, Argentina. Consideraciones taxonómicas y tafonómicas. Ameghiniana 48: 568-588.

Mancuso, A.C.; Chemale, F.; Barredo, S.; Ávila, J.N.; Ottone, E.G.; Marsicano, C. 2010. Age constraints for the northernmost outcrops of the Triassic Cuyana Basin, Argentina. Journal of South American Earth Sciences 30 (2): 97-103.

Martynov, I.I. 1820. Tekhno-botanicheskiislovar: na latinskom i rossiiskom iazykakh. Imperatorskaia Rossiiskaia Akademiya VI: 682 p. Saint Petersburg.

Massabie, A.C. 1986. Filón capa Paramillos de Uspallata, su caracterización geológica y edad, Paramillo de Uspallata, Mendoza. Primeras Jornadas sobre Geología de Precordillera 1: 325-330.

Melchor, R.N.; Genise, J.F. y Poiré, D.G. 2001. Icnología de los depósitos continentales triásicos. In E1 Sistema Triásico en la Argentina (Artabe, A.E.; Morel, E.M.; Zamuner, A.B.; editors). Fundación Museo de La Plata "Francisco Pascasio Moreno": 185-198. La Plata.

Menéndez, C.A. 1951. La flora mesozoica de la Formación Llantenes (provincia de Mendoza). Revista del Museo Argentino de Ciencias Naturales "Bernardino Rivadavia", Ciencias Botánicas 2: 147-261.

Meyen, S.V. 1984. Basic features of gymnosperm systematics and phylogeny as shown by fossil the record. The Botanical Review 50: 1-111.

Meyen, S.V. 1987. Fundamentals of Palaeobotany. Chapman and Hall, London, 432 p.

Morel, E.M. 1991. Estudio paleoflorístico y paleoambiental de la secuencia triásica en el área de Cacheuta, provincia de Mendoza. Ph.D. Thesis (Unpublished), Facultad de Ciencias Naturales y Museo, Universidad Nacional de La Plata 368 p.

Morel, E.M. 1994. El Triásico del Cerro Cacheuta, Mendoza (Argentina). Parte 1: Geología, contenido paleoflorístico y cronoestratigrafía. Ameghiniana 31: 161-176.

Morel, E.M.; Artabe, A.E. 1993. Floras Mesozoicas. In Geología y recursos Naturales de Mendoza (Ramos, V.A.; editor). Congreso Geológico Argentino, No. 12 y Congreso de Exploración de Hidrocarburos, No. 2, Relatorio: 317-324. Mendoza.

Morel, E.M.; Artabe, A.E.; Ganuza, D.G.; Zuñiga, A. 2010. La paleoflora triásica del cerro Cacheuta, provincia de Mendoza, Argentina. Bryopsida, Lycopsida, Sphenopsida, Filicopsida y Gimnospermopsida (Corystospermales y Peltaspermales). Ameghiniana 47: 3-23. 
Morel, E.M.; Artabe, A.E.; Ganuza, D.G.; Zuñiga, A. 2011. La paleoflora triásica del cerro Cacheuta, provincia de Mendoza, Argentina. Petriellales, Cycadales, Ginkgoales, Voltziales, Coniferales, Gnetales y Gimnospermas incertae sedis. Ameghiniana 48 (4): 520-541.

Morris, J. 1845. Fossil fauna. In Strzelecki, P. E. de, Physical description of New South Wales and Van Diemen's Land. Longman, Brown, (Green and Longmans, Eds): 261-312. London.

Nathorst, A.G. 1906. Über Dictyophyllum und Camptopteris spiralis. Kungliga Svenska Vetenskapsakademiens Handlingar 41: 3-24.

Ottone, E.G. 2006. Plantas triásicas del Grupo Rincón Blanco, provincia de San Juan, Argentina. Ameghiniana 43: 477-486.

Ottone, E. G.; Avellaneda, D.; Koukharsky, M. 2011. Plantas triásicas y su relación con el volcanismo en la Formación Agua de la Zorra, provincia de Mendoza, Argentina. Ameghiniana 48 (2): 177-188.

Pedernera, T.E, Benavente, C.A.; Mancuso, A.C.; Ottone, E.G. 2016. Paleoenvironmental reconstruction of the Triassic lacustrine system from the Agua de la Zorra Formation, Cuyana Basin, Mendoza, Argentina. In Congreso de la Asociación Paleontológica Argentina, No. 11, Resúmenes: 178 p. General Roca.

Pedernera, T.E; Benavente, C.A.; Larriestra, F.; Erra, G.; Mancuso, A.C.; Ottone, E.G. 2017. Paleontología y geoquímica de la Formación Agua de laZorra, Triásico Medio a Superior de la Cuenca Cuyana, provincia de Mendoza. In Congreso de Geológico Argentino, No. 20, Actas: 41. San Miguel de Tucumán, Argentina.

Petriella, B. 1979. Sinopsis de las Corystospermaceae (Corystospermales, Pteridospermophyta) de Argentina. 1. Hojas. Ameghiniana 16: 81-102.

Petriella, B. 1982. Sistemática y vinculaciones de las Corystospermaceae H. Thomas. Ameghiniana 18 (3-4): 221-234.

Poma, S.; Litvak, V.D.; Koukharsky, M.; Maisonnave, E. B.; Quenardelle, S. 2009. Darwin's observation in South America: what did he find at Agua de la Zorra, Mendoza province. Revista de la Asociación Geológica Argentina 64 (1): 13-20.

Radczenko, G.P. 1957. Particularités morphologiques et anatomiques de certains types de végetaux du Carbonifère ancien de la province de Kutznetsk. Sbornik Pamyatovat' A.N. Kryhstofovich, Institut botanicheskii Komarov, Akademiya Nauk: p. 33-54. Leningrad (Saint Petersburg).

Ramos, V. A.; Kay, S. M. 1991. Triassic rifting and associated basalts in the Cuyo basin, central Argentina. In Andean magmatism and its tectonic setting (Harmon, R.S.; Rapela, C.W). Geological Society of America 265: 79-91. Boulder, Colorado.

Retallack, G.J. 1977. Reconstructing Triassic vegetation of eastern Australasia: a new approach for the biostratigraphy of Gondwanaland. Alcheringa 1: 247-277, fiche 1: G1-J17.

Retallack, G.J. 1980. Middle Triassic megafossil plants and trace fossil from Tank Gully, Canterbury, New Zealand. Journal of the Royal Society of New Zealand 10: 31-63.

Retallack, G.J. 1981. Middle Triassic megafossil plants from Long Gully, near Otematata, north Otago, New Zealand. Journal of the Royal Society of New Zealand 13: 107-127.

Retallack, G.J.; 1984. Completeness of the rock and fossil record: Sorne estimates using fossil soils. Paleobiology 10: 59-78.

Rößler, R.O. N.N.Y.; Zierold, T.; Feng, Z.; Kretzschmar, R.; Merbitz, M.; Annacker, V. andSchneider, J.W. 2012. A snapshot of an early Permian ecosystem preserved by explosive volcanism: new results from the Chemnitz Petrified Forest, Germany. Palaios 27 (11): 814-834.

Rusconi, C. 1967. Animales extinguidos de Mendoza y de la Argentina. Imprenta Oficial, Mendoza: 489 p.

Schimper, W.P. 1869. Traité de paléontologie végétale ou la flore du monde primitif dans ses rapports avec les formations géologiques et la flore du monde actuel. Tome Premier. J.B. Baillère et Fils: 738 p. Paris.

Sharma, B.D. 2001. Misinterpretations about the 'Pentoxyleae' - A Mesozoic gymnospermous group of plants. The Palaeobotanist 50: 255-265.

Smith, A.R.; Pryer, K.M.; Schuettpelz, E.; Korall, P.; Schneider, H.; Wolf, P.G. 2006. A classification for extant ferns. Taxon 55: 705-731.

Spalletti, L.A.; Morel, E.M.; Artabe, A.E.; Zavattieri, A.M.; Ganuza, D. 2005. Estratigrafía, facies y paleoflora de la sucesión triásica de Potrerillos, Mendoza, República Argentina. Revista geológica de Chile 32 (2): 249-272.

Spalletti, L.A.; Fanning, C.M.; Rapela, C.W. 2008. Dating the Triassic continental rift in the southern Andes: the Potrerillos Formation, Cuyo basin, Argentina. Geologica Acta: an international earth science journal 6 (3): 267-283.

Spicer, R.A. 1991. Plant Taphonomic Processes. In Taphonomy: Releasing the Data Locked in the Fossil Record. Topics in Geology 9 (Allison, P.A.; Briggs, D.E.G.; editors). Plenum Press: 71-113. New York. 
Stappenbeck, R.; Richard, F. A. 1910. La Precordillera de San Juan y Mendoza, por el Dr. Richard Stappenbeck. Talleres de publicaciones de la oficina meteorológica Argentina.

Stewart W.N.; Rothwell, G.W. 1993. Paleobotany and the evolution of plants. Second Edition. Cambridge University Press XII: 521 p. Cambridge.

Stipanicic,C.A.; Marsicano, C.A. (editors) 2002. Léxico Estratigráfico de la Argentina. Volumen 8. Triásico. Asociación Geológica Argentina, Buenos Aires, Serie "B" (Didáctica y Complementaria) 26: 370 p.

Stipanicic, P. N.; Archangelsky, S. 2002. Megafloras. Léxico Estratigráfico de la Argentina: Triásico, Volumen VIII, Serie" B" (Didáctica y Complementaria), Asociación Geológica Argentina: 309-313. Buenos Aires.

Stipanicic, P.N.; Bonetti, M.I. 1969. Consideraciones sobre la cronología de los terrenos triásicos argentinos. In Simposio Internacional sobre Estratigrafía y Paleontología del Gondwana, No. 1: 1081-1119.

Stipanicic, P.N.; Morel, E.M. 2002a. Formación Los Colorados. In Léxico Estratigráfico de la Argentina Volumen 8. Triásico (Stipanicic, P.N.; Marsicano, C.A.; editors). Asociación Geológica Argentina, Buenos Aires, Serie “B” (Didáctica y Complementaria) 26: 179.

Stipanicic, P.N.; Morel, E.M. 2002b. Formación Paramillo. En: P.N. Stipanicic y C.A. Marsicano (Eds.), Léxico Estratigráfico de la Argentina. Volumen 8. Triásico. Asociación Geológica Argentina, Buenos Aires, Serie "B" (Didáctica y Complementaria) 26: 221.

Stipanicic, P.N.; Zavattieri, A.M. 2002. Grupo Uspallata. En: P.N. Stipanicic y C.A. Marsicano (eds.), Léxico Estratigráfico de la Argentina. Volumen 8. Triásico. Asociación Geológica Argentina, Buenos Aires, Serie "B" (Didáctica y Complementaria) 26: 290-294.

Stipanicic, P.N.; Herbst, R.; Bonetti, M.I.R. 1996. Floras Triásicas. In Revisión y actualización de la obra paleobotánica de Kurtz en la República Argentina (Stipanicic, P.N.; Hünicken, M.A. editors). Academia Nacional de Ciencias, Actas 11: 127-198. Córdoba.

Stipanicic, P.N.; Morel, E.M.; Zúñiga, A.E. 2002. Formación Agua de la Zorra. En: P.N. Stipanicic and C.A. Marsicano (eds.), Léxico Estratigráfico de la Argentina. Volumen 8. Triásico. Asociación Geológica Argentina, Buenos Aires, Serie "B" (Didáctica y Complementaria) 26: 27-28.

Strelkov, E.E.; Alvarez, L.A. 1984. Análisis estratigráfico y evolutivo de la cuenca triásica mendocina-sanjuanina. In Congreso Geológico Argentino, No. 9: 115-130.

Swanson, F. J.; Jones, J. A.; Crisafulli, C. M.; Lara, A. 2013. Effects of volcanic and hydrologic processes on forest vegetation: Chaitén Volcano, Chile Andean Geology 40 (2): 359-391.

Szajnocha, L. 1889. Über fossile Pflanzereste aus Cacheuta in der Argentinischen Republik. Sitzungsberichte der Kaiserlichen Akademie der Wissenschaften, Mathematisch-Naturwissenschaftliche Classe 97 (Jahrgang 1888): 219-245.

Taylor, T.N.; Taylor, E.L.; Krings, M. 2009. Paleobotany. The biology and evolution of fossil plants. Elsevier, XIX: 1230 p. Amsterdam.

Tenison-Woods, J.E. 1883. On the fossil flora of coal deposits of Australia. Proceedings of the Linnean Society of New South Wales 8: 37-167.

Thomas, H.H. 1933. On some pteridosperms plants from the Mesozoic rocks of South Africa. Philosophical Transactions of the Royal Society B: Biological Sciences 222: 193-265.

Thoreau, H.D. 1993. Faith in a seed: The dispersion of seeds and other late natural history writings. Island Press. Washington.

Tonrow, J.A. 1967. Fossil plants from Allan and Carapace Nunataks, and from the upper Mill and Shackleton Glaciers, Antarctica. New Zealand Journal of Geology and Geophysics 10: 456-473.

Townrow, J.A. 1957. On Dicroidium, probably pteridospermous leaf, and other leaves now removed from this genus. Transactions of the Geological Society of South Africa 60: 21-60.

Troncoso, A.; Gnaedinger, S.; Herbst, R. 2000. Heidiphyllum, Rissikia y Desmiophyllum (Pinophyta, Coniferales) en el Triásico del norte chico de Chile y sur de Argentina. Ameghiniana 37: 119-125.

Turland, N.J.; Wiersema, J.H.; Barrie, F.R.; Greuter, W.; Hawksworth, D.L.; Herendeen, P.S.; Knapp, S.; Kusber, W.-H.; Li, D.-Z.; Marhold, K.; May, T.W.; McNeill, J.; Monro, A.M.; Prado, J.; Price, M.J.; Smith, G.F. 2018. International Code of Nomenclature for algae, fungi, and plants (Shenzhen Code) adopted by the Nineteenth International Botanical Congress Shenzhen, China, July 2017. Regnum Vegetabile 159. Glashütten: Koeltz Botanical Books: 254 p.

Uliana, M.A.; Biddle, K.T. 1988. Mesozoic-Cenozoic paleogeographic and geodynamic evolution of southern South America. Revista Brasileira de Geociências 18: 172-190.

Van Konijnenburg-van Cittert, J.H.A.; Pott, C.; Cleal, C.J.; Zijlstra, C. 2017. Differentiation of the fossil leaves assigned to Taeniopteris, Nilssoniopteris and Nilssonia with a comparison to similar genera. Review of Palaeobotany and Palynology 237: 100-106. 
Villar de Seoane, L. 1996. Equisetites pusillus sp. nov. from the Aptian of Patagonia, Argentina. Revista del Museo Argentino de Ciencias Naturales, nueva serie, 7: 43-49.

von Berchtold, B.W.H.; Presl, J.S.; 1820. O přirozenosti Rostlin, obsahugjcj gednánj o žiwobytj rostlin pro sebe a z ohledu giných žiwoků, podlé stawu nyněgss ylo znanj, pýtwu rostlin; názwoslowj audů; hospodářstwj gegich; rozssjřenj po semi a způsob rostlinář zřjditi a zacowati. Krala Wiljma Endersa: 324 p. Prague.

Walkom, A.B. 1925. Notes on some Tasmanian Mesozoic plants. Part I. Papers and Proceedings of the Royal Society of Tasmania 1924: 73-89.

White, P.S.; Pickett, S.T. 1985. Natural disturbance and patch dynamics: An introduction. Unknown Journal, 3-13.
Windhausen, H. 1941. El "Rético" del Paramillo de Uspallata (Mendoza). Tesis Doctoral 28. Universidad Nacional de La Plata: 72 p. Inédita.

Wood, D.M.; Del Moral, R. 1988. Colonizing plants on the pumice plains, Mount St. Helens, Washington. American Journal of Botany: 1228-1237.

Yrigoyen, M.R.; Stover, L.E. 1970. La palinología como elemento de correlación del Triásico en la Cuenca Cuyana. 4as. Jornadas Geológicas Argentinas (Mendoza), Actas 2: 427-447.

Zamuner, A.B.; Zavattieri, A.M.; Artabe, A.E.; Morel, E.M. 2001. Paleobotánica. In El Sistema Triásico en la Argentina. (Artabe, A.E.; Morel, E.M.; Zamuner, A.B.; editors). Fundación Museo de La Plata "Francisco Pascasio Moreno": 143-184. La Plata.

Manuscript received: Agosto 14, 2018; revised/accepted: January 4, 2019; available online: February 4, 2019. 